\title{
Review \\ MicroRNA Mediated Plant Responses to Nutrient Stress
}

\author{
Waqar Islam ${ }^{1,2,3,4, *,+}$ D , Arfa Tauqeer ${ }^{5,+}$, Abdul Waheed ${ }^{1,2,+}$ and Fanjiang Zeng ${ }^{1,2,3,4, *}$ \\ 1 Xinjiang Key Laboratory of Desert Plant Roots Ecology and Vegetation Restoration, Xinjiang Institute of \\ Ecology and Geography, Chinese Academy of Sciences, Urumqi 830011, China; drwaheed@ms.xjb.ac.cn \\ 2 State Key Laboratory of Desert and Oasis Ecology, Xinjiang Institute of Ecology and Geography, \\ Chinese Academy of Sciences, Urumqi 830011, China \\ 3 Cele National Station of Observation and Research for Desert-Grassland Ecosystems, Cele 848300, China \\ 4 University of Chinese Academy of Sciences, Beijing 100049, China \\ 5 College of Horticulture, FAFU-UCR Joint Center and Fujian Provincial Key Laboratory of Haixia Applied \\ Plant System Biology, Fujian Agriculture and Forestry University, Fuzhou 350002, China; \\ arfa.tauqeer@yahoo.com \\ * Correspondence: waqarislam@m.fafu.edu.cn or waqarislam@ms.xjb.ac.cn (W.I.); zengfj@ms.xjb.ac.cn (F.Z.) \\ $\dagger$ These authors contributed equally in this article.
}

check for updates

Citation: Islam, W.; Tauqeer, A.; Waheed, A.; Zeng, F. MicroRNA Mediated Plant Responses to

Nutrient Stress. Int. J. Mol. Sci. 2022, 23, 2562. https://doi.org/10.3390/ ijms 23052562

Academic Editors: Abir U.

Igamberdiev and Bartolome Sabater

Received: 25 January 2022

Accepted: 23 February 2022

Published: 25 February 2022

Publisher's Note: MDPI stays neutral with regard to jurisdictional claims in published maps and institutional affiliations.

Copyright: (c) 2022 by the authors. Licensee MDPI, Basel, Switzerland. This article is an open access article distributed under the terms and conditions of the Creative Commons Attribution (CC BY) license (https:/ / creativecommons.org/licenses/by/ $4.0 /)$.

\begin{abstract}
To complete their life cycles, plants require several minerals that are found in soil. Plant growth and development can be affected by nutrient shortages or high nutrient availability. Several adaptations and evolutionary changes have enabled plants to cope with inappropriate growth conditions and low or high nutrient levels. MicroRNAs (miRNAs) have been recognized for transcript cleavage and translational reduction, and can be used for post-transcriptional regulation. Aside from regulating plant growth and development, miRNAs play a crucial role in regulating plant's adaptations to adverse environmental conditions. Additionally, miRNAs are involved in plants sensory functions, nutrient uptake, long-distance root transport, and physiological functions related to nutrients. It may be possible to develop crops that can be cultivated in soils that are either deficient in nutrients or have extreme nutrient supplies by understanding how plant miRNAs are associated with nutrient stress. In this review, an overview is presented regarding recent advances in the understanding of plants' responses to nitrogen, phosphorus, potassium, sulfur, copper, iron, boron, magnesium, manganese, zinc, and calcium deficiencies via miRNA regulation. We conclude with future research directions emphasizing the modification of crops for improving future food security.
\end{abstract}

Keywords: abiotic stresses; environmental constraints; genetic regulations; major nutrients; plant nutrition; arid environment

\section{Introduction}

The normal development and growth of plants requires at least 17 elements. The mineral nutrients comprise 14 of the 17 essential nutrients, the others being oxygen, carbon, and hydrogen [1]. To obtain optimum tissue and cellular development, the concentrations level of these mineral nutrients should be managed with in limited physiological ranges after absorption by plant roots. However, the nutrient compositions of agricultural systems or natural habitats vary, and some must make up for severe nutrient deficiencies [2]. Micronutrients and macronutrients that are not available in enough or excessive amounts can cause nutrient stress. This is rapidly becoming the most serious environmental stress, which has a negative impact on normal growth and development [3]. According to researchers, plants have evolved efficient mechanisms to observe their nutritional status and adapt to variations in nutrient concentrations [4-6]. With the success of the genome sequencing of plants and through the development of new genomic tools, several regulatory elements have been identified as being involved in plant responses to nutritional stress $[7,8]$. These elements, which include nutrient transporter protein, transcriptional factors, rib regulators, and associated proteins, create a complex regulation system that allows the plant to detect 
nutrient stress and modify itself in response by altering a wide range of physiochemical, biological, structural, and biochemical mechanisms [9].

In recent years, miRNAs have been found to be involved to plant stress responses through the post-transcriptional regulation of a variety of transcription factors (TFs) [10-13]. miRNAs are small, intracellular solitary, non-coding RNAs (19 to 24 base pairs), and they are recognized to mediate endogenous expression. They are derived from single stranded (SS)-RNA and have a helical secondary structure [14,15]. Plants usually transcribe miRNAs from separate MIR genes by RNA polymerase II interactions, resulting in 5' capped, 3' polytailed miRNA molecules (Figure 1) [16]. Dicer-like 1 (DCL1) proteins synthesize miRNAs from pri-miRNAs to create catalyst miRNAs, which are then recognized by other DCL1 proteins, which go on to form miRNA/miRNA* duplexes [17]. The RNA-induced silencing complex (RISC) catalyzes the associations of miRNAs with target transcripts using an argonaute (AGO) protein, which is incorporated into a duplex miRNA strand. This helps the AGO to attach to targets through sequence complementarity. The miRNA* strand is often weakened after the fully-developed strand is released [16].

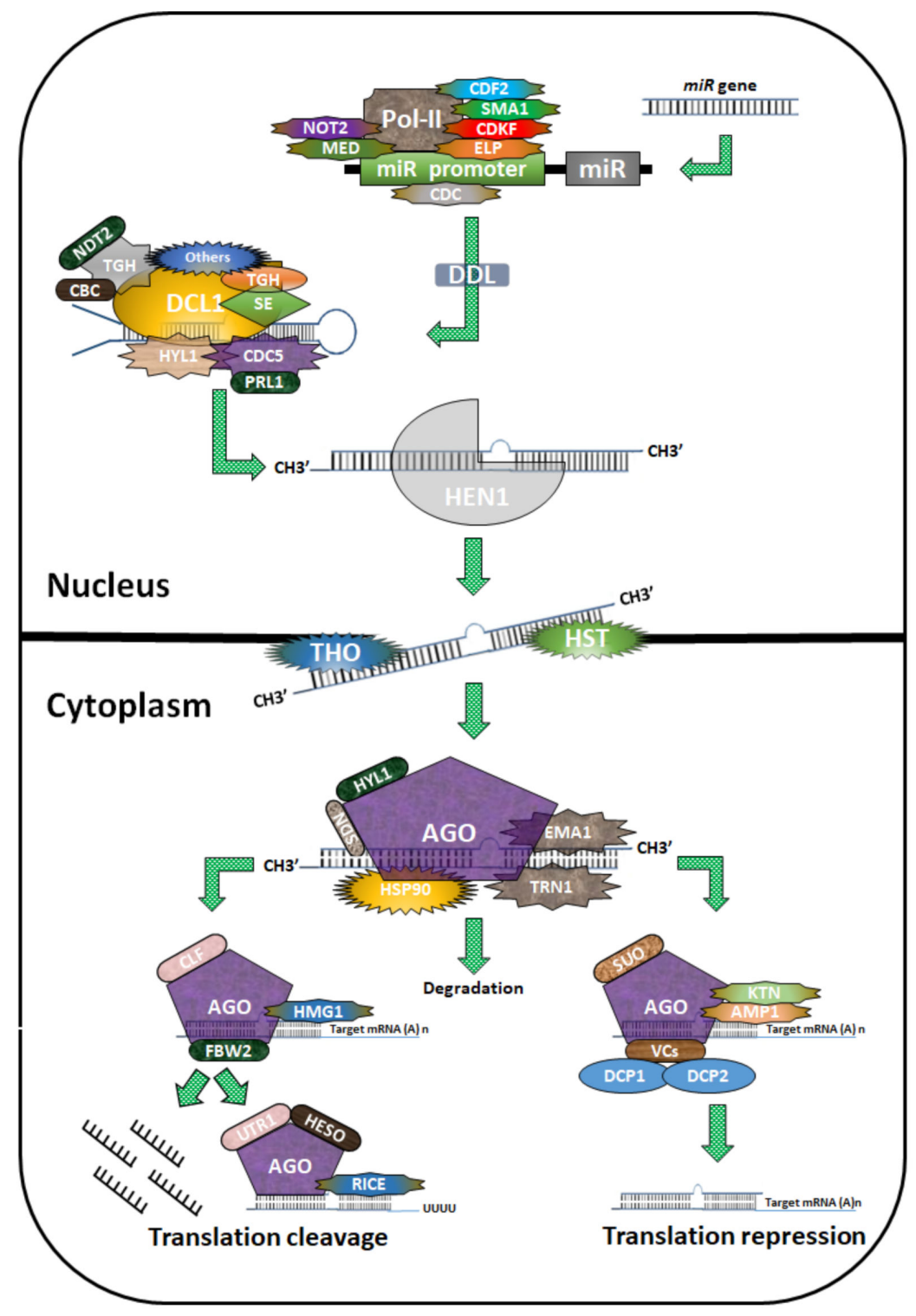

Figure 1. Biogenesis of miRNAs in plants. The diagram depicts miRNA biogenesis in plants. Pol II first transcribes miR genes into pri-miRNAs, leading to the formation of a hairpin structure. The process is regulated by cycling DOF transcription factors (CDF2), SMALL1 (SMA1), cyclin-dependent 
protein kinase (CDKF), extension gene (ELP), a protein containing the MYB domain (CDC), Mediator2 (MED2), and NOT2. During nuclear splicing and processing, the cap-binding protein complex (CBC including CBP20 and CBP80HYL1), PRL1 (an evolutionarily conserved WD-40 protein), DDL, TGH, and SERRATE (SE) paly regulatory roles. Dicer-Like 1 (DCL1) progressively processes pri-miRNAs and pre-miRNAs to produce one or more phased miRNA/miRNA* duplexes, which are methylated by HUA enhancer 1 (HEN1) and delivered to the cytoplasm by HST1 (HASTY). The miRNA is chosen and integrated into a specific argonaute1 (AGO1)-containing RISC (RNA-induced silencing complex), which guides translation inhibition or cleavage of the target mRNA transcript.

Plant growth and development are regulated by miRNAs [14]. Plants use miRNAs to respond to a variety of biotic and abiotic stressors, such as nutritional stress [18]. Plant miRNAs have been shown to be sensitive to a wide range of nutritional stressors, including nitrogen, phosphorus, potassium, sulfur, copper, iron, boron, magnesium, manganese, zinc, and calcium deficiencies and fluctuations (Table 1). miRNAs that are responsive to nutrient stress and their corresponding targets are summarized in this review. Moreover, miRNAs are described briefly in the context of their regulatory role in modulating the responses of plants to nutrient stress.

\section{2. microRNAs in Nutrient Stress}

\section{1. miRNAs and Nitrogen Stress}

Nitrogen $(\mathrm{N})$ is an important factor mainly found in amino acid residues, peptides, nucleotides, cofactors, and a wide variety of secondary plant substances; therefore, it is vital for plant development and rehabilitation [19]. Even though $\mathrm{N}$ is present in soil in a variety of forms, plant roots absorb $\mathrm{N}$ as nitrates and ammonium in a systematic manner [20]. The accessibility of $\mathrm{N}$ to plant root systems is commonly a critical barrier for growing plants and the yields of crops [21]. Plants have developed a number of strategies to adapt to variations in $\mathrm{N}$ availability in soil, including structural, physical, and metabolic adaptations [22]. A clear link between inorganic $\mathrm{N}$ transporters and cell wall construction has been established via a variety of co-expressed remodeling enzymes. Pectin and xyloglucan production enzymes were shown to be significantly co-regulated with $\mathrm{N}$ transporters, implying a link between $\mathrm{N}$ assimilation and cell wall growth regulation [23].

miRNA functions have been investigated in response to nitrate and $\mathrm{N}$ deficiency in the past few years. In response to N, miR167 and miR393 restrict root growth [24]. Moreover, several other $\mathrm{N}$ starvation responsive miRNAs have been discovered in plants using in situ hybridization, small RNA (sRNAs) sequencing at high efficiency, real-time quantitative reverse transcription-polymerase chain reaction (qRT-PCR), and hybridization microarray analyses (Table 1). In cotton, miR167 is a well-known regulated miRNA that targets two auxin response factors (ARFs), i.e., ARF6 and ARF8 [25]. Based on microarray hybridization of roots, it was shown that ARF8 was expressed in pericyclic and horizontal root cap cells of nitrate-treated Arabidopsis roots [26]. Utilizing qRT-PCR and $\beta$-glucuronidase (GUS) fusion analysis, it was concluded that nitrogen induces ARF8 and inhibits miR167. Additionally, it was discovered that ARF8-GUS binding to a mutant miR167-binding site has ongoing negative effects on nitrate regulation. This evidence supports the theory that miR167 suppression causes ARF8 accumulation in pericycle cellular process in response to nitrate analysis [27]. Nitrate regulation of lateral root emergence was completely lost in genetically modified plants expressing miR167 and ARF8 blank mutants. Consequently, the miR167 or ARF8 module controls adventitious root plants' responses to $\mathrm{N}$, and even more so, $\mathrm{N}$ metabolic enzymes that are produced by downstream of nitrification and absorption [24]. Furthermore, it was discovered that miR167 is extra sensitive to $\mathrm{N}$ deficiency in maize [28] and in Arabidopsis [29] indicating that miR167 has vital roles in monocots and dicots' adaptation to N-limited conditions.

miR393 was discovered to be stimulated by nitrate via eliminating the $\mathrm{N}$ oxidase null mutations. Furthermore, activation of miR393 was observed by glycine and ammonium nitrate [30]. Research findings indicate that miR393 is activated by the $\mathrm{N}$ signal transmitted during nitrification and absorption [31]. miR393 specifically targets the basic helix-loop- 
helix (bHLH) signaling pathway bHLH77 and the phytohormones sense organs, e.g., auxin signaling F-box proteins (AFB3, AFB2) and TIR1 (Toll/interleukin-1 receptor) [32]. Individually, the phytohormone sensing organ AFB3 is influenced through miR393-mediated N treatment. Moreover, nitrate regulates auxin-receptive and auxin associated genes that are uninfluenced by auxin treatment, including ARF18 and ARF9 [33]. Furthermore, nitrate had no effect on main root development in miR393-overexpressing plants or afb3-1 mutants, meaning that the miR393/AFB3 regulation module is essential for modifying root development and for the response to $\mathrm{N}$ deficiency [34]. In addition to main root development, the miR393/AFB3 element controls horizontal root development in the reaction to nitrate treatment. These findings show that miR393 and AFB3 control nitrate-produced variations in root structure, potentially through the auxin-signaling pathway.

It was discovered that $\mathrm{N}$ deficiency significantly downregulates Arabidopsis miR169, and target nuclear transcription factor Y subunit-alpha (NFYA) genes, NFYA8, NFYA5, and NFYA2 [29,35]. Other research found that miR169a is downregulated by $\mathrm{N}$ deficiency in Arabidopsis shoots and roots, and that it is essential under N-limited conditions, for the regulation of NFYA expression [36,37] (Figure 1). When compared to wild-type plants, transgenic plants that overexpressed miR169a acquired less $\mathrm{N}$ and were more susceptible to $\mathrm{N}$ deficiency. It has been shown that extreme susceptibility to $\mathrm{N}$ uptake occurs in miR169a-overexpressing plants, and that this is strongly correlated with inhibition of nitrate transport system (NRT) genes, AtNRT2.1 and AtNRT1.1, by the TF called NF-YA [29]. The miR169 gene has also been found in soybeans, maize, and wheat, which contributes to plant tolerance to fluctuations in $\mathrm{N}$ levels [38].

Using various methods, many N-responsive miRNAs in plant species have been discovered (Table 1). qRT-PCR analysis in Arabidopsis indicated that some pri-miR169s and pri-miR398a are suppressed by $\mathrm{N}$ deficiency [39]. Next-generation sequencing data revealed that nine different types of miRNA were suppressed by nutrient deficiency in Arabidopsis; and five miRNA families were stimulated, including miR857, miR398, miR397, and miR395 [40]. Nine novel miRNAs that are responsive to nutrient deficiency were discovered [29]. According to molecular marker techniques, 15 miRNA types were discovered to be overexpressed in rice, and susceptibility to low $\mathrm{N}$ is determined by miRNAs, showing miRNAs' importance [41]. Several research groups have discovered N-receptive miRNAs in maize [42-45] (Table 1). There are 14 miRNA types in maize that are susceptible to transiently or chronically low $\mathrm{N}$ levels, as determined using two genotyping systems [45]. Five preserved families (miR171, miR528, miR395, miR827, and miR169) differentially expressed in maize were identified using northern blot analysis [44]. The $\mathrm{N}$-deficient maize plants were found to downregulate six miRNAs, including miR408, miR169, miR166, miR528, miR528*, and miR169*, using genotype, qRT-PCR, and in situ hybridization analysis in maize [42]. Most of the genes assumed to be targeted by N-responsive miRNAs are translated by plants growth. They are involved signal transmission, nutrient composition, and oxidation pressure susceptibility, indicating that these miRNAs can be associated with managing numerous physical reactions in response to $\mathrm{N}$ deficiency (Table 1 ).

\section{2. miRNAs and Phosphate Stress}

Phosphate $(\mathrm{P})$ is the most important inorganic nutrient for root development and efficiency. Other than being a structural element of basic organic compounds such as nucleotides and phosphatide, $\mathrm{P}$ is also linked to energy transmission, energy production, metabolism, and amino acid synthesis in plants. [46]. There is a limited amount of $\mathrm{P}$ in soil that is available to plants by absorption through the soil and rainfall/transformation into biological forms [46]. Plants often alter their root morphologies and architectures to manage low P stress followed by root cell wall adaptations. Cell wall proteins have been shown to play important roles in the synthesis of cell walls, transmission of signals, and protecting of cells from environmental stress [47].

Recently, it was discovered that miRNAs perform regulatory roles in plants' responses to $P$ deficiency. By downregulating its target gene, ubiquitin C (UBC24) (also known as 
phosphate starvation-responsive gene, PHO2), miR399 controls P metabolism by $\mathrm{P}$ addition, division, and demobilization [48]. UBC24 codes an E2 regulatory protein-associated enzyme with miR399 target sites in its 5' UTR [49]. miR399 was discovered to be firmly and precisely upregulated by $\mathrm{P}$ deficiency, suggesting that $\mathrm{P}$ deficiency inhibits the expression of UBC24 [50]. Upregulation of miR399 in Arabidopsis enhances P intake and distribution to the shoot, resulting in an overabundance of P in the shoot [51]. Genetically modified rice (specifically, Oryza sativa spp.) transcriptionally upregulating osa-miR399f or osamiR399j showed similar phenotypes [52]. Additionally, it was found that heterologous upregulation of Arabidopsis miR399 in tomato resulted in improved P availability in both roots and shoots, improved transport of protons from roots, and improved proton excretion from shoots [53]. Characteristics of miR399-upregulating plants and ubc24-T-DNA mutants equally represent the characteristics of a pho2 mutant [54]. Phosphate slows and suppresses P starvation-induced PSI genes in pho2 mutants or miR399-upregulating plants, which consist of IPS1 (insensitive to phospate starvation 1) and the P carrier genes, further showing that $\mathrm{PHO} 2$ deficiency resembles $\mathrm{P}$ starvation, both of which contribute significantly to $\mathrm{P}$ over-abundance in shoots at below adequate P situations [55,56] (Figure 2). Although the PHO2-moderated decomposition of PHO1 on the endomembrane is necessary to regulate $\mathrm{P}$ homeostasis, other unidentified aspects controlled by $\mathrm{PHO} 2$ may occur to account for the toxic effects of $\mathrm{P}$ on physical composition [57]. Phosphate starvation response-1 (PHR1), PHR1-like 1 (PHL1), and MYB (myeloblastosis) transcription regulators are regulators of $P$ deficiency, as miR399 restricts miR399 transcription and its activity [58]. Phr1-mutants could not upregulate miR399 during P deficiency, showing that PHR1 may suppress miR399 by attaching to P1BS in promoter regions [59]. Recently, it was discovered that Arabidopsis miR399f is controlled by the P deficiency protein IPS1 and is not carved from miR399, resulting in less movement of miR399, thereby protecting $\mathrm{PHO} 2$ transcription from division [60].

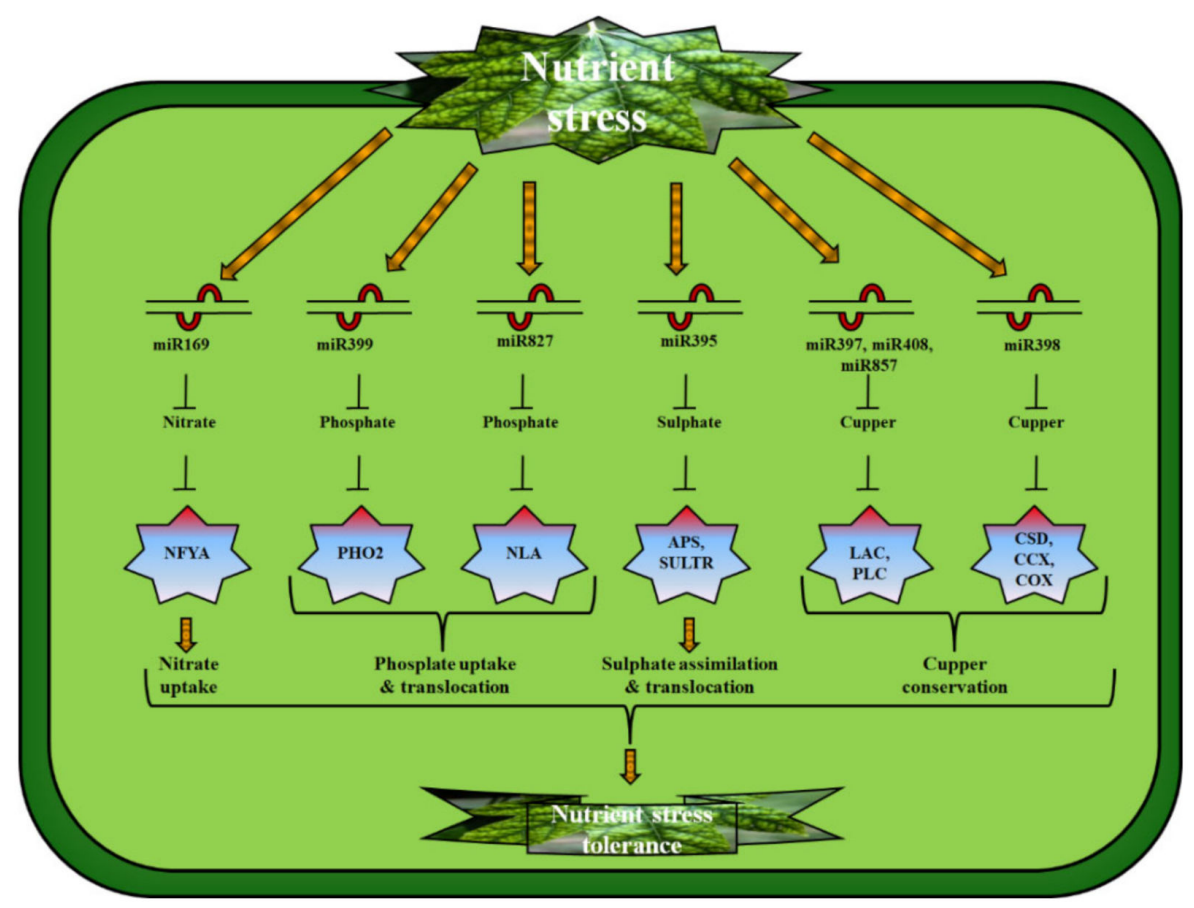

Figure 2. Plant microRNAs: their genetic targets and corresponding functions that induce tolerance against nutrient stress. miR169. miR399, miR827, miR395, miR397, miR408, MiR857, and miR398 respond to $\mathrm{N}, \mathrm{P}, \mathrm{S}$, and $\mathrm{Cu}$ stress via targeting nuclear transcription factor $\mathrm{Y}$ subunit-alpha (NFYA), phosphate starvation-responsive gene (PHO2), nitrogen limitation adaptation (NLA), ATP sulfurylase (APS), sulfate transporter (SULTR), laccases (LAC), cold shock domain (CSD), and cyclooxygenase (COX) to regulate $\mathrm{N}$ uptake, $\mathrm{P}$ uptake and translocation, $\mathrm{S}$ assimilation, and $\mathrm{Cu}$ conservation in plants, respectively, thereby having active roles in nutrient stress tolerance. 
In Arabidopsis, miR827 plays a specific role in $\mathrm{P}$ homeostasis by inhibiting the expression of NLA (nitrogen limitation adaptation) (Figure 2). A 2-NLA mutant exhibited suppression of $\mathrm{P}$ transport-related genes, i.e., PHD finger protein 1 (PHF1) and phosphate transporter 1 (PHT1). An NLA mutant's initial maturating phenotype was considered to be affected by extreme $\mathrm{P}$ deposition in limited $\mathrm{N}$ conditions. NLA functions as a nutrientdependent mechanism for maintaining P homeostasis [61]. In addition, NLA mutant plants presented morphologies like those of P-poisoned plants. Remarkably, the P concentrations in the miR827 variant and the NLA-upregulating plants were comparable [61]. Arabidopsis miR827 responded similarly to rice miR827 when P deficiency was present. The major facilitator superfamily (OsSPX-MFS1 and OsSPX-MFS2) proteins are formed by dividing two SPX-MFS. Astonishingly, P detection is accomplished by two different OsSPX-MFSencoding genes; OsSPX-MFS1, and OPSPX-MFS2, which have indicated opposite reactions to $\mathrm{P}$ deficiency [62]. Moreover, it was observed that osspx-mfs1 mutants improved $\mathrm{P}$ concentrations by reducing $P$ remobilization from old to matured leaves, indicating that the miR827/SPX-MFS1 element controls the P balance in rice plants [62]. Numerous other plant species, including Arabidopsis [63], maize [64], white lupine [65], soybean [66,67], and wheat [68], have been shown to contain P-responsive microRNAs (Table 1).

\section{3. miRNAs and Potassium Stress}

In addition to photosynthesis, osmoregulation, and enzyme activation, potassium (K) is critical to many plant processes, such as cell turgor regulation, cellular expansion, modulation of the cell membrane's electric potential, and balancing of the $\mathrm{pH}$. It influences transcription and post-transcriptional processes. It can be used to maximize crop yields, as it is an important component for plant growth and development [69,70]. Though it is possible that certain cellular mechanisms which are involved have been uncovered, the morphological and physiological adaptations used by plants to cope with $\mathrm{K}$ deficiency remain a mystery. In order to maximize crop yield and quality, further research into $\mathrm{K}$ deficiency's effects on plants is necessary, including identifying the mechanisms leading to the observed changes.

Although some studies suggest certain miRNAs are involved in signal transduction in plants, the exact mechanisms by which they regulate $\mathrm{K}$ uptake is unknown. Specifically, the dormancy-associated MADS-box (OsMADS23) target gene was significantly upregulated in K deficiency, and Osa-miR444a apparently regulates both $\mathrm{N}$ and $\mathrm{P}$ accumulations [71]. A further consequence of the low K conditions was the induction of Hvu-miR319, which repressed growth response factor (HvGRF) expression, which promoted Hvu-miR396 transcription in barley [72]. A number of miRNAs have shown differential expression under low-K stress, including Hvu-miR160a, Hvu-miR169h, and Hvu-miR396c, which are implicated in regulating different photosynthetic processes [73].

Recently, researchers have disclosed that cotton and wheat's miRNA expression was altered by low dietary $\mathrm{K}$ availability (Table 1 ). On the other hand, the $\mathrm{K}$ deficiency resulted in altered expression of 16 out of 20 miRNAs, four days and at eight days after transfection, the exceptions being miR393, miR395, miR396, and miR778 [74,75]. In response to K deficiency, wheat may increase root growth and nutrient uptake through molecular mechanisms. In peanut plants, root development is influenced by miRNAs that play critical roles in K deficient conditions. miR156 and miR390 have been proposed to be upregulated in K deficiency, along with miR160, miR164, and miR393. A miRNA-mediated pathway and mechanism may be responsible for peanuts' responses to $\mathrm{N}$ and $\mathrm{K}$ deficiency stresses [76].

RISC modulates the regulatory pathway by AGO1 in tomatoes via miR168. There has been no conclusive evidence pointing to the function of miR168 in regulating AGO1 in tomatoes under K deficiency stress. SlmiR168 and its target gene expression differ among tomato plants tolerant of low K (JZ34) and those sensitive to low K (JZ18). Pri-SlmiR168expressing transgenic tomato plants demonstrated superior plant development and $\mathrm{K}$ content in roots in a K-deficit environment to non-transgenic or wild-type tomato plants. It was observed that 35S:rSlAGO1 tomatoes exhibited differential upregulation of various 
miRNAs as compared to wild type tomatoes. In 35S:SlmiR168a plants, miRNA levels were much lower than in WT plants. The root growth and cytokinin (CTK)/abscisic acid (ABA) pathways were regulated by $12 \mathrm{miRNAs} / \mathrm{mRNAs}$ that were identified in the integrated analysis. Low-K stress enhances the development of plants via SlmiR168 regulation of SIAGO1A. This regulation mechanism affects CTK/ABA and root growth modulation pathways [77].

The targets of miRNAs detected in Tibetan wild barley cultivated two days or seven days after low-K stress have been identified through bioinformatic predictions and degradome analysis. In total, 65 miRNAs were identified that expressed differently under low-K stress. miR164c, miR169h, and miR395a modules are able to communicate with the tricarboxylic acid (TCA) cycle and other important pathways, i.e., glycolysis and pentose phosphate pathways. Low-K stress appears to regulate $\mathrm{Ca}^{2+}$ signaling through osa-miR166 and ghr-miR482. These miRNAs are thought to be involved in the ethylene production process in plants growing in low-K environments. Some miRNAs implicated in photosynthetic regulation under low-K stress, such as miR160a, miR396c, and miR169h, differed across two barley genotypes, implying that these selectively expressed miRNAs and their targets are critical for plants in low-K environments. [73].

\section{4. miRNAs and Sulfate Stress}

Many plant metabolites require sulfate (S), including carbohydrates and proteins, sulfolipids, and micronutrients, which are all important for physiological functions [78]. Following the significant reductions in anthropogenic sulfur emissions, less $\mathrm{S}$ accessibility in top soil limits plant growth [79]. The most common sulfur form consumed and translocated into different tissues for absorption is inorganic S. Sulfate uptake from topsoil is primarily accomplished through two high-affinity $S$ carriers, SULTR1;1 (sulfate transporter1;1) and SULTR1;2 (Sulfate transporter1;2). Low-affinity S carriers, such as SULTR2;1, SULTR2;2, and SULTR3;5, are used in plants during $S$ transfer [80]. Sulfate acclimatization occurs via plasmidic ATP sulfurylase (APS), which can be deposited in vesicles or absorbed in chloroplasts [81].

A sulfate deficit affects miR395 while targeting the APS1 and APS3 genes (and the SULTR2-1 gene) directly [82] (Figure 2). All six Arabidopsis miR395 genes have been identified that are induced by $S$ starvation using transgenic genetically modified (GM) plants containing miR395 promoter-GFP reporter [83]. The overexpression of miR395 resulted in the downregulation of the APS4, APS1, and SULTR2-1 transcripts after S deprivation $[82,83]$. Tissue-specific occurrence results show that miR395 was identified largely in phloem associated cells, whereas SULTR2-1 is found predominantly in cells of the xylem $[83,84]$. miR395 thus has the ability to limit SULTR2-1 expression in the xylem in the absence of SULTR2-1. miR395 can overcome articulation of SULTR2-1 in phloem companion cells, which may subsequently promote $S$ uptake in the phloem from roots to shoots while inhibiting shoot-to-root transfer in the xylem (Figure 2) [84]. The TF named SLIM1 (Sulphur limitation 1) belongs to the EIL (ethylene-insensitive-like) family. It regulates miR395 expression [85]. Sulfate deficit stimulates SLIM1; one of the critical regulators of the S starvation reaction, SULTR1-2; and other S-starvation response genes. In contrast to miR395 activation in wild-type plants, slim 1 mutants treated by $S$ deprivation showed no significant differences in miR395 expression [85]. Activation of miR395 by SLIM1 is essential for enhanced S transfer from roots to shoots, ensuring effective $S$ incorporation in the shoots. Though it is unknown whether SLIM1 regulates miR395 accumulation directly or indirectly, recent evidence for miR395's regulatory role in S hybridization and assimilation has been reported [84]. Despite showing S deficiency symptoms, miR395-overexpressing plants showed higher $S$ concentrations in their shoots than land race plants. These $S$ over-accumulator mutant plants' paradoxical phenotype of $S$ deficiency could be caused by $S$ assimilation and $S$ relocation between leaves. The fact that miR395-overexpressing plants have characteristics like the aps1-1-sultr2 triple mutant endorses this theory. Findings show that miR395 influences $S$ transport between 
leaves by cleaving SULTR2 and regulates $\mathrm{S}$ deposition in the shoot via targeting APS genes (Figure 2) [83]. Furthermore, miR395 was shown to respond to metabolites that control S absorption, indicating that miR395 may possibly have a role in the $S$ assimilation regulatory network. The molecular process that controls the expression of miR395 in the S integration pathway, however, remains unknown [86]. There is evidence that MiR395 has been detected in the genomes of Sorghum bicolor, Brassica napus, O. sativa, Medicago truncatula, and Solanum lycopersicum $[38,87,88]$. The regulatory pathway miR395/APS-SULTR2 is now known to be maintained in plants. Lack of $S$ alters expression of miR156, miR160, miR164, miR167, miR168, and miR394 in B. napus [89], in addition to miR395, implying that they are involved in $\mathrm{S}$ adaptation (Table 1).

\section{5. miRNAs and Copper Stress}

Many metal proteins require copper $(\mathrm{Cu})$ as a cofactor, including plastocyanin, superoxide dismutase (SOD), laccases (LAC), and cytochrome C oxidase [90]. A Cu shortage in plants causes a variety of issues, including restricted growth and production. On the other hand, $\mathrm{Cu}$ accumulation limits plant development and affects cellular activities, such as photosynthetic electron transport [91]. Several molecular pathways involved in cell wall development and other cellular dynamics include chloroplastic and mitochondrial $\mathrm{Cu}$ transport and homeostasis [92]. Numerous approaches for regulating $\mathrm{Cu}$ homeostasis in plants have evolved, involving a diverse set of proteins and genes [91]. Plants have been found to respond to $\mathrm{Cu}$ deficiencies through miRNAs (miR398, miR397, miR408, and miR857) [93]. miR398, is articulated by three Arabidopsis miR398 genes; cyclooxygenase (COX5b-1), cold shock domain (CSD1 and CSD2), encoding subunits of mitochondrial cytochrome C oxidase; and $\mathrm{Cu}$ chaperone for SOD (CCS1 and CSD2, encoding cytosolic and chloroplast CSD, respectively) $[90,93,94]$. Cu deficiency significantly increases miR398 expression. CSD1 and CSD2 are its target genes, which are reduced [94] (Figure 2). Cu deficiency also activates Fe-SOD, which substitutes $C S D$ functionally. Reduced $\mathrm{Cu}$ availability for other $\mathrm{Cu}$ proteins such as plastocyanin may result from reducing Cu-containing protein CSD [95]. Nevertheless, when exposed to high $\mathrm{Cu}$ stress, miR398 expression decreases, because of which CSD1 and CSD2 are induced post-transcriptionally [94] (Figure 2). When exposed to significant $\mathrm{Cu}$ stress, through $C S D$, superoxide radicals can be effectively purified and $\mathrm{Cu}$ protein synthesis can be increased. GM crops expressing an amiR398-resistant version of CSD2 are hence significantly extra resistant to oxidative stresses, such as great $\mathrm{Cu}$ strain [94].

miR398 plays an important role in the regulation of $\mathrm{Cu}$ homeostasis by downregulating the non-significant $\mathrm{Cu}$ proteins when $\mathrm{Cu}$ concentrations are low or high (Table 1). Non-essential $\mathrm{Cu}$ proteins, including laccases and plastocyanin, have also been discovered to be targeted by miR397, miR408, and miR857 [95,96]. These three miRNAs, like miR398, were enhanced by $\mathrm{Cu}$ stress, and their appearance patterns were found to be inversely linked with those of their corresponding target genes [95]. Moreover, these three supplementary $\mathrm{Cu}$-responsive miRNAs can aid in the optimization of $\mathrm{Cu}$ supply for the critical Cu-comprising TF in Arabidopsis, i.e., SPL7 (SQUAMOSA promoter binding protein-like 7) [97]. Similarly, SPL7 has been demonstrated to regulate miR397, miR398, miR408, and miR857 expression as well [97]. A number of studies have shown that SPL7 binds to its target, the miR398 promoter, which is necessary and sufficient for the in vivo response to Cu deficiency. Unlike miR398b and miR398c, miR398a's promoter sequence lacks the GTAC motifs, which could explain why miR398a has a lower expression level and is less sensitive to $\mathrm{Cu}$ shortage. However, miR398 and miR398c, the spl7 mutant, had considerably decreased echelons of miR397a, miR408, and miR857, demonstrating that SPL7 stimulates Cu-responsive miRNA transcription. SPL7 appears to be a key player in regulating $\mathrm{Cu}$ proteins, including laccases, plastocyanin, and $\mathrm{Cu} / \mathrm{Zn} \mathrm{SOD}$, through Cu-receptive miRNAs [97]. 


\section{6. miRNAs and Boron Stress}

Boron (B) is required for appropriate plant growth and development. It participates in a variety of physiological activities, including cell wall maintenance, lipid metabolism, cell division, protein and nucleic acid metabolism, and cell division [98]. A few studies have found that miRNAs are involved in B-stress responses (Table 1). For example, the B-stress responsive miRNA network and its corresponding pathways have been studied in barley [99]. Furthermore, the researchers compared the miRNA profiles of root and leaf samples. The existence of 31 recognized and three novel miRNAs in barley was studied, with 25 of them demonstrating a B-treatment response. In certain tissues, miRNAs expressed specifically; e.g., miR156, miR171, miR397, and miR444 were only expressed in leaves. The miRNAs specifically targeted and degraded 934 barley transcripts. When computing the target genes of miRNAs, in silico analysis uncovered that many of the miRNA target genes were conserved, including TFs such as SPLs, ARFs, and MYBs. Most of these target genes were related to plant development and responses to environment changes. Several miRNAs in barley, including miR408, may play critical roles in protecting the plant from B exposure [99]. Furthermore, qRT-PCR analysis of French beans (Phaseolus vulgaris L.) exposed to high levels of $B$ revealed differences in miRNA expression. miRNA targets were also studied for their impacts on gene expression during B stress. It was confirmed by GO (Gene Ontology) that plant miRNAs have roles in a number of cellular activities, including the circadian cycle and vegetative development [100].

$B$ deficiency is a problem that is widely prevalent among citrus trees. Citrus species have been shown to contain B-responsive miRNAs in a few studies. The results of highthroughput Illumina sequencing (HTIS) in Citrus sinensis roots revealed 52 upregulated and 82 downregulated miRNAs. This demonstrates roots' amazing metabolic plasticity, which may help plants tolerate B deprivation [101]. It was proposed that several aspects of miRNAs may affect the adaptation of roots to B-deficiency such as (a) upregulating miR474 and downregulating miR782 and miR843 to scavenge reactive oxygen species (ROS); (bboosting the expression of miR394 and lowering the expression of miR5023, thus making cells more sensitive to B-deficiency; (c) downregulating miR830, miR5266, and miR3465 transcripts to improve fluid transport in cells; (d) regulating osmo-protection via miR474 and other metabolic reactions through miR5023 and miR821. It was exhibited that the expression of other miRNAs, including miR472 and miR2118 in roots, was decreased as B-deficiency occurred, resulting in the reduction of diseases resistance genes leading towards the decrease in root disease resistance [101]. Similarly, RNA transcript analysis in trifoliate orange (Poncirus trifoliata) revealed a decrease in miR397 levels after excess B-treatment. Excess B treatment increased the transcription of laccase7 (LAC7), the target of miR397. This treatment also increased laccase activity significantly establishing that LAC7 plays a vital role in protein biosynthesis [102]. Furthermore, HTIS identified miRNAs and their differential expression patterns in leaves of $C$. sinensis (tolerant) and C. grandis (intolerant) treated with B. Molecular and anatomical approaches were used to verify candidate miRNAs [103]. After B-toxic treatment, 51 miRNAs were differently expressed in C. grandis, whereas 20 miRNAs were significantly expressed in C. sinensis. In B-treated C. sinensis leaves, miR395a was significantly upregulated, but miR397a was downregulated. The $5^{\prime}$-RACE study of four ARF genes and two laccase (LAC) genes revealed that they are miR160 and miR397's true targets. A downregulation of LAC17, whereas an upregulation of LAC4, caused poor vessel development in C. grandis. In C. sinensis vessels, secondary deposition of cell-wall polysaccharides occurred. miR397a plays a vital role in woody cell wall formation by targeting LAC17 and LAC4, which are involved for secondary cell wall synthesis [103]. Similarly, the HTIS of seeds of 'Xuegan' [C. sinensis Osbeck] revealed the upregulation of 91 and downregulation of 81 miRNAs in B-deficient leaves. There are several possible mechanisms by which miRNAs adapt to B-deficiency: (a) As a result of altered TIR1 expression, and alterations in the expression of miR393, miR160, and miR3946, deficient auxin signaling results in diminished plant growth and development; (b) upregulation of NACs and the maintenance of leaf phenotype 
through miR159, miR782, miR3946, and miR7539; (c) downregulation of the expression of miR164, miR6260, miR5929, miR6214, miR3946, and miR3446 induced stress responses and antioxidant system; (d) reducing the expression of miR5037-targeted major facilitator superfamily protein genes, thus limiting B export from plants. A plant's tolerance to Bdeficiency might also be influenced by the downregulation of miR408, which regulates $\mathrm{Cu}$ homeostasis and enhances SOD activity [104]. In another Citrus study utilizing HTIS, from root tissues of tolerant C. grandis and intolerant C. grandis treated with B toxicity, distinct miRNA expressions were discovered [105]. Overall, in response to B poisoning, 37 miRNAs were differently expressed. 5'-RACE and qRT-PCR results showed that MYB gene, a SCARECROW-like protein gene, and a cation transporting ATPase gene were the targets of miR319, miR171, and miR396g-5p, respectively. When SCARECROW expression is maintained in B-treated Citrus roots, stem cells and the endodermis remain specified, allowing root extension under B-toxic circumstances. Downregulation of MYB owing to miR319 upregulation in C. grandis roots treated with B-toxicity might substantially alter root system architecture by diminishing root tips. miR319 and miR171 appear to play a critical role in Citrus tolerance to long-term B toxicity by targeting MYB and SCARECROW, both of which are involved in root growth and development [105].

B-toxicity was shown to have a substantial effect on genes encoding jasmonate (JA), ethylene, and a cell wall modifier in wheat. Arabidopsis was investigated under hazardous B circumstances to evaluate the expression levels of miRNAs (miR172 and miR319) that target JA and ethylene-related TFs, and miR397, which targets laccase. The expression of mature miRNA was analyzed by stem-loop qRT-PCR [106]. Mild B toxicity (condition 1B) significantly increased the expression levels of miRNAs targeting TFs involved in JA and ethylene metabolism, but not severe B toxicity (condition 3B). Arabidopsis was most significantly regulated by miR172 and miR319 genes. miR397 expression did not significantly change under B toxicity, demonstrating that laccase-induced modifications to the cell wall are not regulated post-transcriptionally. As well as targeting TFs related to JA and ethylene metabolism through miRNAs, Arabidopsis can detect oxidative stress and adapt to B toxicity by producing these miRNAs [106]. To address disparities in performance under high levels of $\mathrm{B}$, the same author group examined the transcriptional regulation of miR319, miR172, and miR398, and their likely target genes, in Bolal-2973 (B-tolerant) and Atay-85 (B-sensitive) wheat cultivars. Expression levels of miR398 in Atay, and $\mathrm{Cu} / \mathrm{ZnSOD}$ gene expression, were higher than in Bolal after exposure to toxic $\mathrm{B}$. As a result, both toxic B and ethylene-related miRNAs (miR172 and miR319) showed stable levels in wheat cultivars, exhibiting that it may induce leaf senescence. Atay, a sensitive cultivar, was only affected by miR172 targeting TF-TOE1. On the other hand, miR319 targeted MYB3 in both cultivars, and MYB3 expression was significantly boosted upon B toxicity. Additionally, the authors determined the Arabidopsis orthologs of the wheat miRNA targets. GO enrichment analyses of miRNA targets were conducted to identify functional protein association networks. According to new research, Triticum aestivum is home to several genes whose targets are miR172, miR319, and miR398. Furthermore, due to interaction amongst miRNA-mediated post transcriptional pathways, miR172, miR319, and miR398 are extremely susceptible to nutritional shortages or toxicities, such as those of Fe, P, B, S, and Cu [107].

\section{7. miRNAs and Magnesium Stress}

The chlorophyll molecule contains the elements magnesium (Mg) and chloride [108]. More than 300 enzymes, including ribulose-1,5-bisphosphate carboxylase, ATPase, protein kinases, phosphatases, glutathione synthase, and many others, use $\mathrm{Mg}$ as a cofactor; and it is an allosteric modulator for a variety of physiological and biochemical processes, including photosynthesis, respiration, organic acid metabolism, and carbohydrate partitioning between source and sink organs $[109,110]$. There is a widespread Mg deficiency in citrus crops, which affects their productivity and quality [111]. Despite this, there are limited data on miRNAs in higher plants that respond to $\mathrm{Mg}$ shortage (Table 1). Mg-deficient $\mathrm{C}$. sinensis 
leaves revealed 75 upregulated and 71 downregulated miRNAs [112]. In addition to their amazing metabolic flexibility, leaf miRNAs' adaptive responses to $\mathrm{Mg}$ shortage are believed to entail numerous aspects: (a) increasing stress-related genes by inhibiting miR3946 and miR5158 expression while increasing miR395, miR1077, miR1160, and miR8019 expression; (b) improving cell transport by inhibiting miR3946 and miR5158 expression while increasing miR395, miR1077, miR1160, and miR8019 expression; (c) repressing miR158, miR5256, and miR3946 to induce lipid metabolism. The researchers also discovered a number of candidate miRNAs that may have roles in Mg deficiency tolerance (i.e., miR7812, miR8019, miR6218, miR1533, miR6426, miR5256, miR5742, miR5561, miR5158, and miR5818). These findings add to our understanding of how plants respond to $\mathrm{Mg}$ shortage [112]. $\mathrm{Mg}$ starved roots also exhibited increased expression of 101 miRNAs and decreased expression of 69 miRNAs via HTIS. Several factors contributed to citrus roots' adaptation to $\mathrm{Mg}$ deficiency, including: (a) inhibiting root respiration (via miR158 and miR2919) by downregulating related miRNAs (miR780); (b) reducing inflammatory mediators by decreasing miRNAs (miR780, miR6190, miR1044, miR5261, and miR1151); (c) increasing the expression of transport-related genes by regulating miR6190, miR6485, miR1044, miR5029, and miR3437 expression; (d) controlling miR544, miR5261, miR1151, and miR5029 expression to increase protein ubiquitination; (e) regulating miR5261, miR6485, and miR158 expression to contribute to root development; and ( $\mathrm{f}$ ) regulating transcriptional regulation of DNA repair by regulating miR5176 and miR6485 [113].

Plant growth and development can be increased by using nanoparticles (NP) at the right time. Plants utilize a variety of mechanisms, including gene expression and microRNAs, to control stress responses and maintain homeostasis. In a recent study, with varied amounts of treatment, MgO-NP altered gene expression, miRNA levels, cell morphology, chlorophyll content, and physiological changes in Ananas comosus var bracteatus. Four grams of MgO-NP significantly increased miR396 and miR398 expression, while simultaneously repressing RHS12 and XTH expression [114].

\section{8. miRNAs in Manganese Stress}

Plant growth is dependent upon the enzymatic processes mediated by manganese (Mn), which is an inorganic catalyst. $\mathrm{Mn}$ is an essential component of plants' biochemical processes, such as photosynthesis, respiration, and nitrogen assimilation. Moreover, it is required for pollen germination, the growth of pollen tubes, root cells' elongation, and protection of roots from root pathogens [115]. Only a few studies have been conducted on Mn toxicity in plants. Further research is required to determine whether miRNAs and their targets can modulate Mn toxicity. Therefore, it is difficult to find comprehensive information about the posttranscriptional regulation of Mn toxicity. Researchers used both miRNA microarray hybridization and qRT-PCR to identify miRNAs responsive to Mn in the common bean (P. vulgaris). According to the study, 37 miRNAs showed differential expression under abiotic and Mn stress conditions. Mn poisoning caused the activation of 11 miRNAs and the inhibition of 11 others. miR1508, miR1515, miR1510/2110, and miR1532 were revealed to be new Mn-responsive miRNAs. Leucine-rich repeat-resistant proteins, receptor kinase proteins, and calcium-dependent protein kinases were identified as key targets among Mn-responsive miRNAs [116]. Additionally, a recent study showed Arabidopsis miRNAs that respond in cell growth, nutrient homeostasis, and ion transport, differentially expressed under Mn stress conditions [117].

\section{9. miRNAs and Iron Stress}

An essential ingredient in hemoglobin is iron (Fe) [118]. Fe is usually inaccessible to plants due to its inadequate solubility in neutral and alkaline soils. Fe toxicity in plants, on the other hand, may be prompted in acidic soils by anaerobic circumstances [119]. In Fe-deficient conditions, plants control the transcriptional and post-transcriptional levels of the molecular cis-elements. In plants, Fe is involved in chlorophyll synthesis and maintenance of chloroplast structure and function [120]. Plants' responses to Fe deficiency 
have recently been proposed to be mediated by miRNAs [121]. Eight unique miRNAs (miR159, miR169, miR172, miR173, and miR394) from five families were preserved in an Fe shortage in Arabidopsis, and indicated being beneficial and differently produced in response to Fe deprivation [122] (Table 1). The promoters of several iron-deficiencyinducible (IDE) genes contain IDE1 and IDE2, which respond to Fe deficiency. Surprisingly, numerous Arabidopsis miRNAs with IDE1/IDE2 patterns in their supporters have been found to be sensitive to Fe deficiency [123]. In Arabidopsis treated with Fe deficiency, seven miRNAs from eight families displayed markedly different expression levels (miR172, miR158, miR163, miR165, miR166, miR397, and miR398) [123]. Similarly, it was observed that miR408 was overexpressed in Fe-deficient Arabidopsis plants [124]. Furthermore, using northern blot analysis and microarrays, in the common bean, multiple miRNAs were found to respond to Fe deficiency, including miR167, miR397, miR398, and miR408 [116].

\subsection{0. miRNA and Other Nutrients}

Plant growth and development are increasingly reliant on zinc $(\mathrm{Zn})$ as a micronutrient [125]. A large percentage of the world's soil is deficient in Zn [126]. Many metabolic reactions in plants are driven by $\mathrm{Zn}$, which is an important component of many enzymes. Plants would cease to grow and their development would be hindered without certain enzymes. Zn-deficient plants produce significantly less carbohydrates, proteins, and chlorophyll [127]. Only a few studies have addressed miRNAs' role in plants responding to Zn deficiency (Table 1). For example, a study using Solexa sequencing identified several miRNAs that responded to Zn deficiency in Brassica juncea roots [128]. Both Zn-deficient and control roots of $B$. juncea contained 101 members of 21 conserved miRNA families. Plants with Zn deficiency and control plants showed differential expression of 15 miRNAs from nine miRNA families. The $\mathrm{Zn}$-deficient roots of $B$. juncea showed upregulated expression of 13 miRNAs, while miR399b and miR845a appeared to be downregulated. Abiotic stress causes $B$. juncea roots to modulate these miRNAs, which control the phytohormone response, plant development, and abiotic stress responses. As a consequence of these discoveries, we now have a better understanding of how miRNA regulates the Zn-deficiency response in plants, and how this affects plant growth and development [128].

Peanuts are the most widely grown cash crop among leguminous plants, owing to their high protein content and ability to produce oil. They are extensively grown in tropical and subtropical climates [129]. Quality and yield are directly impacted by the development of peanut embryos. Geocarpic plants, such as peanuts, go through a complicated embryo development process that involves a number of gene regulation mechanisms at both the transcriptional and posttranscriptional levels, and these are easily influenced by soil components, such as calcium (Ca) [130]. Ca in the soil (pegging zone) is essential for the development of embryos. The yield and quality of peanuts are severely reduced when calcium is deficient [131]. Deficient Ca also adversely affects seed viability and germination after a season. Peanut embryos are born dead as a result of severe soil calcium deficiency. A recent study focused on analyzing the sRNAs in early peanut embryos with the aid of a recently established platform for the sequences of genomes of wild peanut species (Table 1). Twelve peanut-specific miRNA families were found to host 29 known miRNAs and 132 potential novel miRNAs. Of the identified miRNAs, 87 showed differential expression during early embryo development in the presence of Ca deficiency or sufficiency, and 117 target genes also showed differential expression [132]. Twenty miRNAs differentially expressed 52 target genes according to an integrated analysis of miRNAs and transcriptome expression. A comparison of gene chip analysis and transcriptome sequencing revealed some targets that were differentially expressed. These results indicate that miRNAs actively modulate the expression of genes associated with embryo development, such as TCP3 (Teosinte branched1/Cycloidea/Proliferating cell factor), AP2 (Apetala 2), EMB2750 (embryo-defective), GRFs, cytochrome P450 (CYP707A1 and CYP707A3), which conveys ABA, and BR1, which transports brassinosteroids (BRs). Both miRNAs and their related target genes are thought to participate in peanut embryo abortion in response to Ca deficiency. 
These findings establish miRNA-mediated regulatory mechanisms implicated in embryo abortion in the absence of $\mathrm{Ca}$ in peanut embryos [132].

Table 1. Nutrient responsive miRNAs: their regulations and target functions in plants.

\begin{tabular}{|c|c|c|c|c|c|c|c|c|c|c|c|c|c|c|}
\hline \multirow{2}{*}{ miRNAs } & \multirow{2}{*}{ Targets } & \multirow{2}{*}{ Plant Species } & \multirow{2}{*}{ Target Function } & \multirow{2}{*}{ Regulation } & \multicolumn{9}{|c|}{ Nutrients } & \multirow[t]{2}{*}{ References } \\
\hline & & & & & $\mathbf{N}$ & $\mathbf{P}$ & K & $\mathrm{S}$ & $\mathrm{Cu}$ & $\mathrm{Fe}$ & B & $\mathrm{Mg}$ & Mn Zn & \\
\hline \multirow{4}{*}{$\operatorname{miR156}$} & SPLs & Camellia sinensis & Shoot development & Up & $\sqrt{ }$ & & & & & & & & & [133] \\
\hline & SPLs & Lupinus angustifolius & Seed development & Up & & $\sqrt{ }$ & & & & & & & & [134] \\
\hline & SPLs & Brassica napus & Seed maturation & Up & & & & $\sqrt{ }$ & & & & & & {$[135]$} \\
\hline & $\begin{array}{l}\text { NAC4, ARF2, } \\
\text { AFB3 }\end{array}$ & Arachis hypogaea & Root development & Up & $\sqrt{ }$ & & & & & & & & & [76] \\
\hline miR157 & SPLs & Citrus sinensis & Root development & Down & & & & & & & $\sqrt{ }$ & & & [101] \\
\hline \multirow{5}{*}{$\operatorname{miR} 158$} & BZIP & Solanum lycopersicum & Plant development & Up & & $\sqrt{ }$ & & & & & & & & [136] \\
\hline & $\begin{array}{c}\text { AP2, SBP, } \\
\text { NAC, MYB }\end{array}$ & Arabidopsis thaliana & Plant development & Up & & & & & & $\sqrt{ }$ & & & & [123] \\
\hline & $\begin{array}{c}\text { AP2, SBP, } \\
\text { NAC, MYB }\end{array}$ & Vitis vinifera & $\begin{array}{l}\text { Plant growth and } \\
\text { development }\end{array}$ & Up & & & & & $\sqrt{ }$ & & & & & [96] \\
\hline & SPLs & Citrus sinensis & $\begin{array}{c}\text { Respiration } \\
\text { management }\end{array}$ & Up & & & & & & & & $\sqrt{ }$ & & [113] \\
\hline & FUT1 & Brassica juncea & $\begin{array}{l}\text { Plant development and } \\
\text { abiotic stress response }\end{array}$ & Up & & & & & & & & & $\sqrt{ }$ & [128] \\
\hline \multirow{4}{*}{$\operatorname{miR} 159$} & $\begin{array}{l}\text { MYBs and } \\
\text { TCPs }\end{array}$ & Cucumis sativus & Plant development & Up & $\sqrt{ }$ & & & & & & & & & [137] \\
\hline & MYBs & Betula luminifera & Root development & Down & & $\sqrt{ }$ & & & & & & & & [138] \\
\hline & NRAMP4 & Oryza sativa & Root development & Up & & & & & & $\sqrt{ }$ & & & & [139] \\
\hline & MYBs & Triticum aestivum & Root development & $\mathrm{Up}$ & $\sqrt{ }$ & & & & & & & & & [140] \\
\hline \multirow{4}{*}{$\operatorname{miR} 160$} & ARFs & Arabidopsis thaliana & $\begin{array}{l}\text { Root development, } \\
\text { signal transduction }\end{array}$ & Up & $\sqrt{ }$ & & & & & & & & & [29] \\
\hline & SPLs & Arachis hypogaea & Root development & Down & $\sqrt{ }$ & & & & & & & & & {$[76]$} \\
\hline & GRFs & Triticum aestivum & Signal transduction & Down & & & $\sqrt{ }$ & & & & & & & {$[74]$} \\
\hline & ARFs & Brassica juncea & Hormone signaling & $\mathrm{Up}$ & & & & & & & & & $\sqrt{ }$ & {$[128]$} \\
\hline \multirow{2}{*}{$\operatorname{miR} 162$} & DCLs & Zea mays & Flower development & $\mathrm{Up}$ & $\sqrt{ }$ & & & & & & & & & {$[28]$} \\
\hline & DCLs & Oryza sativa & Iron homeostasis & $\mathrm{Up}$ & & & & & & $\sqrt{ }$ & & & & [141] \\
\hline \multirow{3}{*}{ miR164 } & NAC & Arabidopsis thaliana & Leaf senescence & Up & $\sqrt{ }$ & & & & & & & & & [51] \\
\hline & SPLs & Arachis hypogaea & Root development & Down & $\sqrt{ }$ & & & & & & & & & {$[76]$} \\
\hline & TCA cycle & Arachis hypogaea & Potassium stress & Up/Down & & & $\sqrt{ }$ & & & & & & & {$[76]$} \\
\hline miR165 & HD-ZIP & Hordeum vulgare & Root development & $\mathrm{Up}$ & & & & & & & $\sqrt{ }$ & & & [99] \\
\hline $\operatorname{miR} 166$ & HD-ZIP & Populus tomentosa & Shoot development & Down & $\sqrt{ }$ & & & & & & & & & {$[142]$} \\
\hline \multirow{3}{*}{$\operatorname{miR} 168$} & AGOs & Cucumis sativus & Signal transduction & Down & $\sqrt{ }$ & & & & & & & & & {$[137]$} \\
\hline & AGOs & Solanum lycopersicum & Root development & Down & & & $\sqrt{ }$ & & & & & & & [77] \\
\hline & AGOs & Oryza sativa & Root development & Up/Down & & & & & & $\sqrt{ }$ & & & & {$[141]$} \\
\hline \multirow{5}{*}{$\operatorname{miR} 169$} & HAP2 & Arabidopsis thaliana & $\begin{array}{l}\text { Nitrogen homeostasis, } \\
\text { stress response }\end{array}$ & Down & $\sqrt{ }$ & & & & & & & & & {$[37]$} \\
\hline & HAP2 & Sorghum bicolor & stress response & Down & & & $\sqrt{ }$ & & & & & & & [143] \\
\hline & $\begin{array}{l}\text { Pentose } \\
\text { pathway }\end{array}$ & Triticum aestivum & Potassium stress & Up/Down & & & $\sqrt{ }$ & & & & & & & [74] \\
\hline & CAAT TFs & Phaseolus vulgaris & Leaf formation & $\mathrm{Up}$ & & & & & & & & & $\sqrt{ }$ & [116] \\
\hline & CAAT TFs & Brassica juncea & Plant development & Up & & & & & & & & & $\sqrt{ }$ & [128] \\
\hline \multirow{4}{*}{ miR171 } & SCLs & Arabidopsis thaliana & Root development & Down & $\sqrt{ }$ & & & & & & & & & [29] \\
\hline & SCLs & Oryza sativa & Root development & Up/Down & & & & & & $\sqrt{ }$ & & & & [141] \\
\hline & $\begin{array}{l}\text { Signaling } \\
\text { pathways }\end{array}$ & Taxus chinensis & Root development & Up/Down & & & & $\sqrt{ }$ & & & & & & [144] \\
\hline & $\begin{array}{l}\text { SCARECROW- } \\
\text { like } \\
\text { protein }\end{array}$ & Citrus sinensis & Root development & Up & & & & & & & $\sqrt{ }$ & & & [105] \\
\hline $\operatorname{miR} 176$ & MLH1 & Citrus sinensis & $\begin{array}{l}\text { Respiration } \\
\text { management }\end{array}$ & Up & & & & & & & & $\sqrt{ }$ & & [113] \\
\hline
\end{tabular}


Table 1. Cont.

\begin{tabular}{|c|c|c|c|c|c|c|c|c|c|c|c|c|c|c|}
\hline \multirow{2}{*}{ miRNAs } & \multirow{2}{*}{ Targets } & \multirow{2}{*}{ Plant Species } & \multirow{2}{*}{ Target Function } & \multirow{2}{*}{ Regulation } & \multicolumn{9}{|c|}{ Nutrients } & \multirow[t]{2}{*}{ References } \\
\hline & & & & & $\mathbf{N}$ & $\mathbf{P}$ & $\mathbf{K}$ & S & $\mathrm{Cu}$ & $\mathrm{Fe}$ & B & $\mathrm{Mg}$ & Mn Zn & \\
\hline \multirow{7}{*}{$\operatorname{miR} 319$} & TCPs & Cucumis sativus & Shoot development & Down & $\sqrt{ }$ & & & & & & & & & [137] \\
\hline & TCPs & Hordeum vulgare & Potassium homeostasis & Down & & & $\sqrt{ }$ & & & & & & & {$[72,73]$} \\
\hline & $\begin{array}{l}\text { Signaling } \\
\text { pathways }\end{array}$ & Taxus chinensis & Root development & Up/Down & & & & $\sqrt{ }$ & & & & & & [144] \\
\hline & MYBs & Citrus sinensis & Root development & Up & & & & & & & $\sqrt{ }$ & & & [105] \\
\hline & $\begin{array}{c}\text { ethylene-related } \\
\text { TFs }\end{array}$ & Arabidopsis thaliana & $\begin{array}{l}\text { oxidative } \\
\text { stress-adaptive } \\
\text { responses }\end{array}$ & Up & & & & & & & $\sqrt{ }$ & & & [106] \\
\hline & MYBs & Triticum aestivum & Nutrient stress response & Up & & & & & & & $\sqrt{ }$ & & & [107] \\
\hline & TCPs & Brassica juncea & Plant development & Up & & & & & & & & & $\sqrt{ }$ & [128] \\
\hline \multirow{2}{*}{$\operatorname{miR} 390$} & $\begin{array}{l}\text { NAC4, ARF2, } \\
\text { and AFB3 }\end{array}$ & Arachis hypogaea & $\begin{array}{c}\text { Lateral root } \\
\text { development }\end{array}$ & Up & $\sqrt{ }$ & & & & & & & & & [76] \\
\hline & $\begin{array}{l}\text { Serine/threonine } \\
\text { protein kinase }\end{array}$ & Phaseolus vulgaris & Nodule formation & Up & & & & & & & & & $\sqrt{ }$ & [116] \\
\hline \multirow{4}{*}{ miR393 } & Auxin receptors & Zea mays & Development of roots & Up & $\sqrt{ }$ & & & & & & & & & {$[42]$} \\
\hline & SPLs & Arachis hypogaea & Root development & Down & $\sqrt{ }$ & & & & & & & & & {$[76]$} \\
\hline & Auxin signaling & Oryza sativa & $\begin{array}{l}\text { Development of } \\
\text { Auxiliary buds }\end{array}$ & Up/Down & $\sqrt{ }$ & & & & & & & & & [145] \\
\hline & $\begin{array}{c}\text { Basic } \\
\text { helix-loop-helix } \\
\text { (bHLH) }\end{array}$ & Brassica juncea & Plant development & Up & & & & & & & & & $\sqrt{ }$ & [128] \\
\hline \multirow{2}{*}{$\operatorname{miR} 394$} & F-box & Oryza sativa & Shoot development & Up & $\sqrt{ }$ & & & & & & & & & [146] \\
\hline & F-Box & Brassica juncea & Plant development & Up & & & & & & & & & $\sqrt{ }$ & [128] \\
\hline \multirow{3}{*}{ miR395 } & $\begin{array}{l}\text { ATP sulfurylase; } \\
\text { Sulfate } \\
\text { transporters }\end{array}$ & Cucumis sativus & Sulfur metabolism & Down & $\sqrt{ }$ & & & & & & & & & [137] \\
\hline & $\begin{array}{l}\mathrm{Ca}^{2+} \text { signaling } \\
\text { pathway }\end{array}$ & Sorghum bicolor & Potassium stress & Up/Down & & & $\sqrt{ }$ & & & & & & & [143] \\
\hline & $\begin{array}{l}\text { ATP sulfurylase; } \\
\text { Sulfate } \\
\text { transporters }\end{array}$ & Arabidopsis thaliana & Nutrient stress response & Down & & & & & & & & & $\sqrt{ }$ & [117] \\
\hline \multirow{6}{*}{$\operatorname{miR396}$} & GRF & Oryza sativa & Leaf development & Down & $\sqrt{ }$ & & & & & & & & & [147] \\
\hline & GRF & Hordeum vulgare & Potassium homeostasis & Down & & & $\sqrt{ }$ & & & & & & & {$[72,73]$} \\
\hline & GRF & Oryza sativa & Seedling growth & Down & $\sqrt{ }$ & & & & & & & & & [147] \\
\hline & GRF & Phaseolus vulgaris & Plant development & Up & & & & & & & $\sqrt{ }$ & & & [100] \\
\hline & RHS12 & $\begin{array}{c}\text { Ananas comosus var. } \\
\text { bracteatus }\end{array}$ & Plant development & UP & & & & & & & & $\sqrt{ }$ & & [114] \\
\hline & GRF & Phaseolus vulgaris & Nodule formation & Up & & & & & & & & & $\sqrt{ }$ & [116] \\
\hline \multirow{4}{*}{ miR397 } & Laccases & Zea mays & $\begin{array}{c}\text { Lignin } \\
\text { synthesis/Copper } \\
\text { homeostasis }\end{array}$ & Down & $\sqrt{ }$ & & & & & & & & & [42] \\
\hline & Laccases & Arabidopsis thaliana & Metabolic processes & Down & & & & $\sqrt{ }$ & & & & & & {$[40]$} \\
\hline & Laccases & Poncirus trifoliata & Stress response & Up & & & & & & & $\sqrt{ }$ & & & [102] \\
\hline & Laccases & Citrus sinensis & Cell wall biosynthesis & Down & & & & & & & $\sqrt{ }$ & & & [103] \\
\hline \multirow{7}{*}{$\operatorname{miR398}$} & $\begin{array}{l}\text { CSD; COX5b-1; } \\
\text { CCS1 }\end{array}$ & Medicago sativa & $\begin{array}{l}\text { Oxidative } \\
\text { stress/Copper } \\
\text { homeostasis }\end{array}$ & Down & $\sqrt{ }$ & & & & & & & & & [148] \\
\hline & SOD & Arabidopsis thaliana & Metabolic processes & Down & & & & $\sqrt{ }$ & & & & & & {$[40]$} \\
\hline & SPLs & Arabidopsis thaliana & Metabolic processes & Down & & & & & $\sqrt{ }$ & & & & & [93] \\
\hline & $\begin{array}{l}\text { GATA type zinc } \\
\text { finger TFs }\end{array}$ & Phaseolus vulgaris & $\begin{array}{c}\text { Regulate } \\
\text { light-sensitivity }\end{array}$ & Down & & & & & & & $\sqrt{ }$ & & & [100] \\
\hline & XTH & $\begin{array}{c}\text { Ananas comosus var. } \\
\text { bracteatus }\end{array}$ & Plant development & UP & & & & & & & & $\sqrt{ }$ & & [114] \\
\hline & $\mathrm{Cu} / \mathrm{Zn} \mathrm{SOD}$ & Brassica juncea & Plant development & Up & & & & & & & & & $\sqrt{ }$ & [128] \\
\hline & Unknown & Arachis hypogaea & Embryo development & Up & & & & & & & & & & [132] \\
\hline
\end{tabular}


Table 1. Cont.

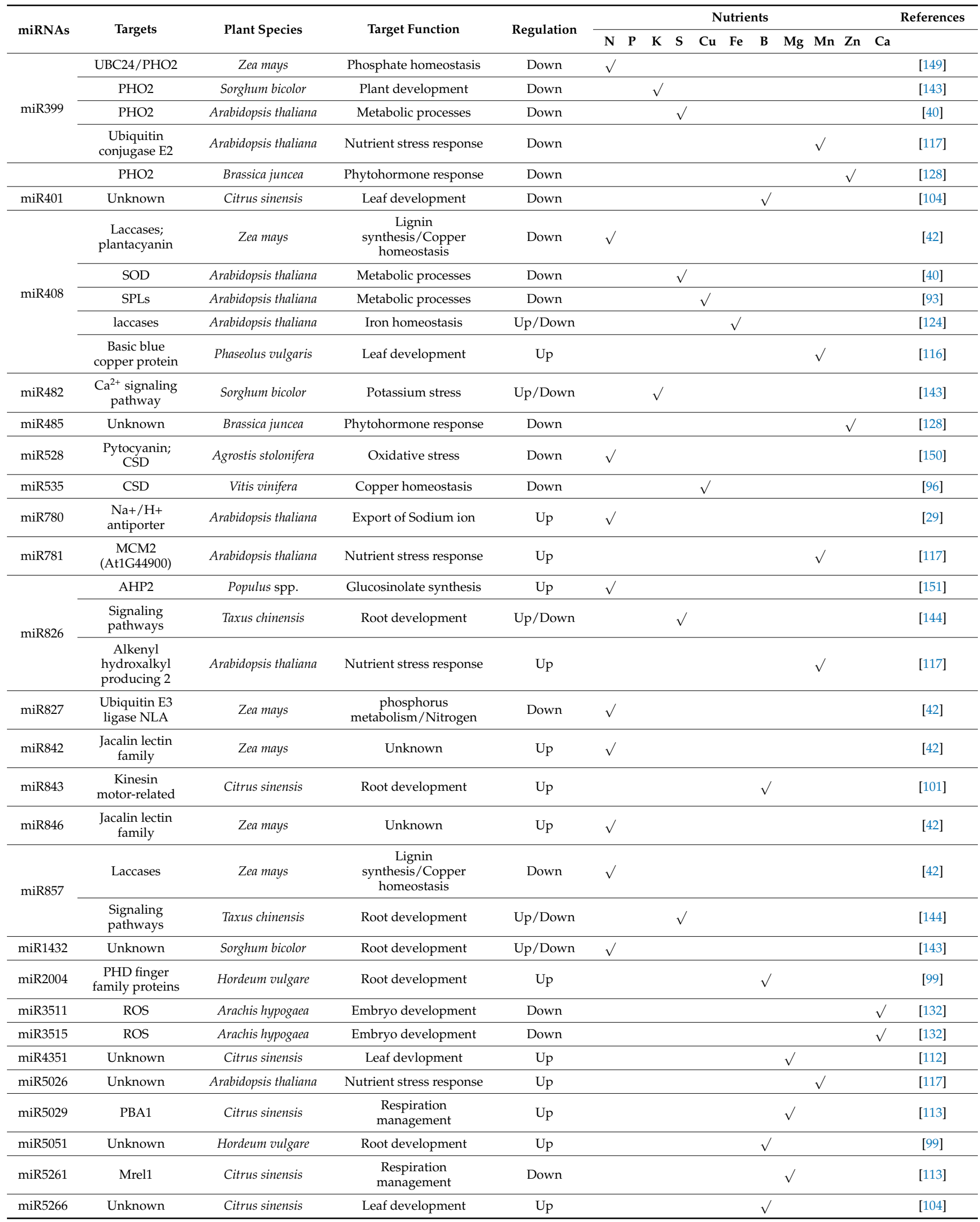


Table 1. Cont.

\begin{tabular}{|c|c|c|c|c|c|c|c|c|c|c|c|c|c|c|}
\hline \multirow{2}{*}{ miRNAs } & \multirow{2}{*}{ Targets } & \multirow{2}{*}{ Plant Species } & \multirow{2}{*}{ Target Function } & \multirow{2}{*}{ Regulation } & \multicolumn{9}{|c|}{ Nutrients } & \multirow[t]{2}{*}{ References } \\
\hline & & & & & $\mathbf{N}$ & $\mathbf{P}$ & K & $\mathrm{S}$ & $\mathrm{Cu}$ & $\mathrm{Fe}$ & B & $\mathrm{Mg}$ & $\mathrm{Mn} \mathrm{Zn}$ & \\
\hline miR5564 & Unknown & Sorghum bicolor & Shoot development & Up/Down & & $\sqrt{ }$ & & & & & & & & {$[143]$} \\
\hline $\operatorname{miR5565}$ & Unknown & Sorghum bicolor & Stress response & Up/Down & & & $\sqrt{ }$ & & & & & & & [143] \\
\hline miR5595 & MES & Arabidopsis thatiana & Nutrient stress response & $\mathrm{Up}$ & & & & & & & & & $\sqrt{ }$ & {$[117]$} \\
\hline miR5832 & Unkonwn & Citrus sinensis & Leaf development & Up & & & & & & & & $\sqrt{ }$ & & {$[112]$} \\
\hline $\operatorname{miR6485}$ & VALRs & Citrus sinensis & $\begin{array}{l}\text { Respiration } \\
\text { management }\end{array}$ & Up & & & & & & & & $\sqrt{ }$ & & [113] \\
\hline
\end{tabular}

Abbreviations: SPLs (SQUAMOSA promoter-binding protein-like), AHP2 (alkenyl hydroxalkyl producing 2), CSD (cold-shock domain), PHO2 (phosphate starvation 2), SOD (superoxide dismutase), COX (cyclooxygenases), GRF (growth response factors), ARF (Auxin response factors), DCL (dicer-like), MYB (myeloblastosis), TCA (tricarboxylic acid cycle), NRAMP4 (natural resistance-associated macrophage protein 4).

\section{Conclusions and Prospects}

Since the discovery of miRNA, many nutrient-receptive miRNAs have been uncovered using diverse methodologies. However, mechanical information about the functions of nutrient-receptive miRNAs still requires further understanding and research. Similarly, more investigations related to these specified miRNAs and their genetic targets will provide us with better insights into the monitoring networks of plants for nutrient stress. Although recent advancements in high-throughput sequencing have enabled us to quickly classify the miRNAs, it is unclear whether these miRNAs, such as miR172 and miR398, regulate targets through translational inhibition or employ some other mechanisms. Moreover, focus should be shifted towards understanding the involvement of miRNAs in nutritional stress responses via paying special attention to phenotypical and physiological changes caused by these regulations. Nutritional stress can also adversely affect transposon-derived RNAs and tRNA-derived RNAs, in addition to miRNAs; however, their physiological roles are unknown. To ensure future food security, miRNA-based strategies could be vital, in order to create crop varieties with higher productivity and resistance to abiotic and biotic stress.

Author Contributions: All the authors contributed to the present form of the manuscript. W.I. collected the data, drafted the manuscript; A.T. and A.W. edited; W.I. created figures and tables; F.Z. supervised; and W.I. finalized and approved the final version of manuscript. All authors have read and agreed to the published version of the manuscript.

Funding: This work was supported by the Program of Joint Funds of the National Natural Science Foundation of China and Xinjiang Uygur Autonomous Region of China (U1903102) and the National Natural Science Foundation of China (41977050).

Institutional Review Board Statement: Not applicable.

Informed Consent Statement: Not applicable.

Data Availability Statement: Not applicable.

Conflicts of Interest: The authors declare no competing interests.

\section{References}

1. Fageria, N.K. The Use of Nutrients in Crop Plants; Routledge: London, UK; Taylor \& Francis: London, UK; England and Wales: London, UK, 2016.

2. Goulding, K.; Murrell, T.S.; Mikkelsen, R.L.; Rosolem, C.; Johnston, J.; Wang, H.; Alfaro, M.A. Outputs: Potassium Losses from Agricultural Systems. In Improving Potassium Recommendations for Agricultural Crops; Springer: Cham, Switzerland, 2021; pp. 75-97.

3. Mee, C.Y.; Balasundram, S.K.; Mohd Hanif, A.H. Detecting and monitoring plant nutrient stress using remote sensing approaches: A review. Asian J. Plant Sci. 2017, 16, 1-8.

4. Schillaci, M.; Kehelpannala, C.; Martinez-Seidel, F.; Smith, P.M.C.; Arsova, B.; Watt, M.; Roessner, U. The metabolic response of brachypodium roots to the interaction with beneficial bacteria is affected by the plant nutritional status. Metabolites 2021, 11, 358. [CrossRef] [PubMed] 
5. Trehan, S.P.; Kumar, M. Improving Nutrient Use Efficiency by Exploiting Genetic Diversity of Crops. In Nutrient Use Efficiency: From Basics to Advance; Springer: New Delhi, India, 2015; pp. 209-220, ISBN 9788132221692.

6. Fageria, N.K.; Baligar, V.C.; Li, Y.C. The role of nutrient efficient plants in improving crop yields in the twenty first century. J. Plant Nutr. 2008, 31, 1121-1157. [CrossRef]

7. Gogolev, Y.V.; Ahmar, S.; Akpinar, B.A.; Budak, H.; Kiryushkin, A.S.; Gorshkov, V.Y.; Hensel, G.; Demchenko, K.N.; Kovalchuk, I.; Mora-Poblete, F.; et al. Omics, epigenetics, and genome editing techniques for food and nutritional security. Plants 2021, 10, 1423. [CrossRef] [PubMed]

8. Islam, W. CRISPR-Cas9; an efficient tool for precise plant genome editing. Mol. Cell. Probes 2018, 39, 47-52. [CrossRef]

9. Song, X.; Li, Y.; Cao, X.; Qi, Y. MicroRNAs and Their Regulatory Roles in Plant-Environment Interactions. Annu. Rev. Plant Biol. 2019, 70, 489-525. [CrossRef]

10. Noman, A.; Sanaullah, T.; Khalid, N.; Islam, W.; Khan, S.; Irshad, M.K.; Aqeel, M. Crosstalk between plant miRNA and heavy metal toxicity. In Plant Metallomics and Functional Omics: A System-Wide Perspective; Springer Nature Switzerland AG: Cham, Switzerland, 2019; pp. 145-168, ISBN 9783030191030.

11. Islam, W.; Noman, A.; Qasim, M.; Wang, L. Plant responses to pathogen attack: Small rnas in focus. Int. J. Mol. Sci. 2018, 19, 515. [CrossRef]

12. Islam, W.; Islam, S.; Qasim, M.; Wang, L. Host-Pathogen interactions modulated by small RNAs. RNA Biol. 2017, 17, 891-904. [CrossRef]

13. Noman, A.; Aqeel, M.; Khalid, N.; Islam, W.; Sanaullah, T.; Anwar, M.; Khan, S.; Ye, W.; Lou, Y. Zinc finger protein transcription factors: Integrated line of action for plant antimicrobial activity. Microb. Pathog. 2019, 132, 141-149. [CrossRef]

14. Islam, W.; Adnan, M.; Huang, Z.; Lu, G.; Chen, H.Y.H. Small RNAs from seed to mature plant. CRC Crit. Rev. Plant Sci. 2019, 38, 117-139. [CrossRef]

15. Islam, W.; Qasim, M.; Noman, A.; Adnan, M.; Tayyab, M.; Farooq, T.H.; Wei, H.; Wang, L. Plant microRNAs: Front line players against invading pathogens. Microb. Pathog. 2018, 118, 9-17. [CrossRef] [PubMed]

16. Gao, Z.; Nie, J.; Wang, H. MicroRNA biogenesis in plant. Plant Growth Regul. 2021, 93, 1-12. [CrossRef]

17. Chen, X. microRNA biogenesis and function in plants. FEBS Lett. 2005, 579, 5923-5931. [CrossRef] [PubMed]

18. Shahzad, R.; Harlina, P.W.; Ayaad, M.; Ewas, M.; Nishawy, E.; Fahad, S.; Subthain, H.; Amar, M.H. Dynamic roles of microRNAs in nutrient acquisition and plant adaptation under nutrient stress: A review. Plant Omics 2018, 11, 58-79. [CrossRef]

19. Masclaux-Daubresse, C.; Daniel-Vedele, F.; Dechorgnat, J.; Chardon, F.; Gaufichon, L.; Suzuki, A. Nitrogen uptake, assimilation and remobilization in plants: Challenges for sustainable and productive agriculture. Ann. Bot. 2010, 105, 1141-1157. [CrossRef] [PubMed]

20. Moreau, D.; Bardgett, R.D.; Finlay, R.D.; Jones, D.L.; Philippot, L. A plant perspective on nitrogen cycling in the rhizosphere. Funct. Ecol. 2019, 33, 540-552. [CrossRef]

21. Maurel, C.; Nacry, P. Root architecture and hydraulics converge for acclimation to changing water availability. Nat. Plants 2020, 6, 744-749. [CrossRef] [PubMed]

22. Trivedi, P.; Leach, J.E.; Tringe, S.G.; Sa, T.; Singh, B.K. Plant-microbiome interactions: From community assembly to plant health. Nat. Rev. Microbiol. 2020, 18, 607-621. [CrossRef] [PubMed]

23. Landi, S.; Esposito, S. Nitrate uptake affects cell wall synthesis and modeling. Front. Plant Sci. 2017, 8, 1376. [CrossRef]

24. Yousuf, P.Y.; Shabir, P.A.; Hakeem, K.R. miRNAomic Approach to Plant Nitrogen Starvation. Int. J. Genomics 2021, $2021,8560323$. [CrossRef] [PubMed]

25. Arora, S.; Singh, A.K.; Chaudhary, B. Target-mimicry based miRNA167-diminution ameliorates cotton somatic embryogenesis via transcriptional biases of auxin signaling associated miRNAs and genes. Plant Cell. Tissue Organ Cult. 2020, 141, 511-531. [CrossRef]

26. Asim, M.; Ullah, Z.; Xu, F.; An, L.; Aluko, O.O.; Wang, Q.; Liu, H. Nitrate signaling, functions, and regulation of root system architecture: Insights from arabidopsis thaliana. Genes 2020, 11, 633. [CrossRef] [PubMed]

27. He, H.; Liang, G.; Li, Y.; Wang, F.; Yu, D. Two young MicroRNAs originating from target duplication mediate nitrogen starvation adaptation via regulation of glucosinolate synthesis in Arabidopsis thaliana. Plant Physiol. 2014, 164, 853-865. [CrossRef]

28. Zhao, M.; Tai, H.; Sun, S.; Zhang, F.; Xu, Y.; Li, W.X. Cloning and characterization of maize miRNAs involved in responses to nitrogen deficiency. PLoS ONE 2012, 7, e29669. [CrossRef]

29. Liang, G.; He, H.; Yu, D. Identification of Nitrogen Starvation-Responsive MicroRNAs in Arabidopsis thaliana. PLoS ONE 2012, 7. [CrossRef]

30. Guan, P. Dancing with hormones: A current perspective of nitrate signaling and regulation in arabidopsis. Front. Plant Sci. 2017, 8. [CrossRef] [PubMed]

31. Sajjad, N.; Bhat, E.A.; Shah, D.; Manzoor, I.; Noor, W.; Shah, S.; Hassan, S.; Ali, R. Nitrogen uptake, assimilation, and mobilization in plants under abiotic stress. In Transporters and Plant Osmotic Stress; Academic Press: Cambridge, MA, USA; Elsevier B.V.: Amsterdam, The Netherlands, 2021; pp. 215-233.

32. Bao, M.; Bian, H.; Zha, Y.; Li, F.; Sun, Y.; Bai, B.; Chen, Z.; Wang, J.; Zhu, M.; Han, N. MiR396a-mediated basic helix-loop-helix transcription factor bHLH74 repression acts as a regulator for root growth in arabidopsis seedlings. Plant Cell Physiol. 2014, 55, 1343-1353. [CrossRef] 
33. Vega, A.; O'Brien, J.A.; Gutiérrez, R.A. Nitrate and hormonal signaling crosstalk for plant growth and development. Curr. Opin. Plant Biol. 2019, 52, 155-163. [CrossRef]

34. Etemadi, M.; Gutjahr, C.; Couzigou, J.M.; Zouine, M.; Lauressergues, D.; Timmers, A.; Audran, C.; Bouzayen, M.; Bécard, G.; Combier, J.P. Auxin perception is required for arbuscule development in arbuscular mycorrhizal symbiosis. Plant Physiol. 2014, 166, 281-292. [CrossRef]

35. Xu, M.Y.; Zhang, L.; Li, W.W.; Hu, X.L.; Wang, M.B.; Fan, Y.L.; Zhang, C.Y.; Wang, L. Stress-induced early flowering is mediated by miR169 in Arabidopsis thaliana. J. Exp. Bot. 2014, 65, 89-101. [CrossRef] [PubMed]

36. Zuluaga, D.L.; Sonnante, G. The use of nitrogen and its regulation in cereals: Structural genes, transcription factors, and the role of miRNAs. Plants 2019, 8, 294. [CrossRef]

37. Zhao, M.; Ding, H.; Zhu, J.K.; Zhang, F.; Li, W.X. Involvement of miR169 in the nitrogen-starvation responses in Arabidopsis. New Phytol. 2011, 190, 906-915. [CrossRef] [PubMed]

38. Zeng, H.; Wang, G.; Hu, X.; Wang, H.; Du, L.; Zhu, Y. Role of microRNAs in plant responses to nutrient stress. Plant Soil 2014, 374 1005-1021. [CrossRef]

39. Pant, B.D.; Musialak-Lange, M.; Nuc, P.; May, P.; Buhtz, A.; Kehr, J.; Walther, D.; Scheible, W.R. Identification of nutrientresponsive Arabidopsis and rapeseed microRNAs by comprehensive real-time polymerase chain reaction profiling and small RNA sequencing. Plant Physiol. 2009, 150, 1541-1555. [CrossRef] [PubMed]

40. Liang, G.; Ai, Q.; Yu, D. Author Correction: Uncovering miRNAs involved in crosstalk between nutrient deficiencies in Arabidopsis. Sci. Rep. 2020, 10, 6912. [CrossRef]

41. Yu, C.; Chen, Y.; Cao, Y.; Chen, H.; Wang, J.; Bi, Y.M.; Tian, F.; Yang, F.; Rothstein, S.J.; Zhou, X.; et al. Overexpression of miR169o, an overlapping MicroRNA in response to both nitrogen limitation and bacterial infection, promotes nitrogen use efficiency and susceptibility to bacterial blight in rice. Plant Cell Physiol. 2018, 59, 1234-1247. [CrossRef]

42. Yang, Z.; Wang, Z.; Yang, C.; Yang, Z.; Li, H.; Wu, Y. Physiological responses and small RNAs changes in maize under nitrogen deficiency and resupply. Genes Genom. 2019, 41, 1183-1194. [CrossRef]

43. Sun, Q.; Liu, X.; Yang, J.; Liu, W.; Du, Q.; Wang, H.; Fu, C.; Li, W.X. MicroRNA528 Affects Lodging Resistance of Maize by Regulating Lignin Biosynthesis under Nitrogen-Luxury Conditions. Mol. Plant 2018, 11, 806-814. [CrossRef] [PubMed]

44. Zhao, Y.; Xu, Z.; Mo, Q.; Zou, C.; Li, W.; Xu, Y.; Xie, C. Combined small RNA and degradome sequencing reveals novel miRNAs and their targets in response to low nitrate availability in maize. Ann. Bot. 2013, 112, 633-642. [CrossRef]

45. Xu, Z.; Zhong, S.; Li, X.; Li, W.; Rothstein, S.J.; Zhang, S.; Bi, Y.; Xie, C. Genome-wide identification of microRNAs in response to low nitrate availability in maize leaves and roots. PLoS ONE 2011, 6, e28009. [CrossRef]

46. Ikhajiagbe, B.; Anoliefo, G.O.; Olise, O.F.; Rackelmann, F.; Sommer, M.; Adekunle, I.J. Major phosphorus in soils is unavailable, yet critical for plant development. Not. Bot. Horti Agrobot. Cluj-Napoca 2020, 12, 500-535. [CrossRef]

47. Wu, W.; Zhu, S.; Chen, Q.; Lin, Y.; Tian, J.; Liang, C. Cell wall proteins play critical roles in plant adaptation to phosphorus deficiency. Int. J. Mol. Sci. 2019, 20, 5259. [CrossRef] [PubMed]

48. Park, B.S.; Seo, J.S.; Chua, N.H. Nitrogen Limitation Adaptation Recruits Phosphate2 to target the phosphate transporter PT2 for degradation during the regulation of Arabidopsis phosphate homeostasis. Plant Cell 2014, 26, 454-464. [CrossRef] [PubMed]

49. Kuo, H.F.; Chiou, T.J. The role of microRNAs in phosphorus deficiency signaling. Plant Physiol. 2011, 156, 1016-1024. [CrossRef] [PubMed]

50. Wang, R.; Fang, Y.N.; Wu, X.M.; Qing, M.; Li, C.C.; Xie, K.D.; Deng, X.X.; Guo, W.W. The miR399-CsUBC24 module regulates reproductive development and male fertility in citrus. Plant Physiol. 2020, 183, 1681-1695. [CrossRef]

51. Park, S.H.; Jeong, J.S.; Seo, J.S.; Park, B.S.; Chua, N.H. Arabidopsis ubiquitin-specific proteases UBP12 and UBP13 shape ORE1 levels during leaf senescence induced by nitrogen deficiency. New Phytol. 2019, 223, 1447-1460. [CrossRef]

52. Rao, S.; Balyan, S.; Jha, S.; Bansal, C.; Das, J.R.; Gupta, A.; Mathur, S. Orchestration of MicroRNAs and Transcription Factors in the Regulation of Plant Abiotic Stress Response. In Plant Stress Biology; Springer: Berlin/Heidelberg, Germany, 2020; pp. 251-277.

53. Gao, N.; Su, Y.; Min, J.; Shen, W.; Shi, W. Transgenic tomato overexpressing ath-miR399d has enhanced phosphorus accumulation through increased acid phosphatase and proton secretion as well as phosphate transporters. Plant Soil 2010, 334, 123-136. [CrossRef]

54. Magalhaes, J.V.; de Sousa, S.M.; Guimaraes, C.T.; Kochian, L.V. The role of root morphology and architecture in phosphorus acquisition: Physiological, genetic, and molecular basis. In Plant Macronutrient Use Efficiency: Molecular and Genomic Perspectives in Crop Plants; Academic Press: Cambridge, MA, USA, 2017; pp. 123-147, ISBN 9780128112946.

55. Song, L.; Yu, H.; Dong, J.; Che, X.; Jiao, Y.; Liu, D. The Molecular Mechanism of Ethylene-Mediated Root Hair Development Induced by Phosphate Starvation. PLoS Genet. 2016, 12, e1006194. [CrossRef]

56. Ceasar, S.A. Regulation of low phosphate stress in plants. In Plant Life Under Changing Environment; Academic Press: Cambridge, MA, USA; Elsevier B.V.: Amsterdam, The Netherlands, 2020; pp. 123-156.

57. Liu, T.Y.; Huang, T.K.; Tseng, C.Y.; Lai, Y.S.; Lin, S.I.; Lin, W.Y.; Chen, J.W.; Chioua, T.J. PHO2-dependent degradation of PHO1 modulates phosphate homeostasis in Arabidopsis. Plant Cell 2012, 24, 2168-2183. [CrossRef] [PubMed]

58. Briat, J.F.; Rouached, H.; Tissot, N.; Gaymard, F.; Dubos, C. Integration of P, S, Fe, and Zn nutrition signals in Arabidopsis thaliana: Potential involvement of Phosphate Starvation Response 1 (PHR1). Front. Plant Sci. 2015, 6, 290. [CrossRef] [PubMed]

59. Rouached, H.; Secco, D.; Arpat, B.; Poirier, Y. The transcription factor PHR1 plays a key role in the regulation of sulfate shoot-to-root flux upon phosphate starvation in Arabidopsis. BMC Plant Biol. 2011, 11, 19. [CrossRef] 
60. Pegler, J.L.; Nguyen, D.Q.; Oultram, J.M.J.; Grof, C.P.L.; Eamens, A.L. Molecular manipulation of the mir396 and mir399 expression modules alters the response of arabidopsis thaliana to phosphate stress. Plants 2021, 10, 2570. [CrossRef] [PubMed]

61. Lin, W.Y.; Huang, T.K.; Chiou, T.J. NITROGEN LIMITATION ADAPTATION, a target of MicroRNA827, Mediates degradation of plasma membrane-localized phosphate transporters to maintain phosphate homeostasis in Arabidopsis. Plant Cell 2013, 25, 4061-4074. [CrossRef]

62. Wang, C.; Huang, W.; Ying, Y.; Li, S.; Secco, D.; Tyerman, S.; Whelan, J.; Shou, H. Functional characterization of the rice SPX-MFS family reveals a key role of OsSPX-MFS1 in controlling phosphate homeostasis in leaves. New Phytol. 2012, 196, 139-148. [CrossRef]

63. Fujii, H.; Chiou, T.J.; Lin, S.I.; Aung, K.; Zhu, J.K. A miRNA involved in phosphate-starvation response in Arabidopsis. Curr. Biol. 2005, 15, 2038-2043. [CrossRef] [PubMed]

64. Zhang, Z.; Lin, H.; Shen, Y.; Gao, J.; Xiang, K.; Liu, L.; Ding, H.; Yuan, G.; Lan, H.; Zhou, S.; et al. Cloning and characterization of miRNAs from maize seedling roots under low phosphorus stress. Mol. Biol. Rep. 2012, 39, 8137-8146. [CrossRef]

65. Zhu, Y.Y.; Zeng, H.Q.; Dong, C.X.; Yin, X.M.; Shen, Q.R.; Yang, Z.M. microRNA expression profiles associated with phosphorus deficiency in white lupin (Lupinus albus L.). Plant Sci. 2010, 178, 23-29. [CrossRef]

66. Sha, A.; Chen, Y.; Ba, H.; Shan, Z.; Zhang, X.; Wu, X.; Qiu, D.; Chen, S.; Zhou, X. Identification of Glycine Max MicroRNAs in response to phosphorus deficiency. J. Plant Biol. 2012, 55, 268-280. [CrossRef]

67. Liu, X.; Chu, S.; Sun, C.; Xu, H.; Zhang, J.; Jiao, Y.; Zhang, D. Genome-wide identification of low phosphorus responsive microRNAs in two soybean genotypes by high-throughput sequencing. Funct. Integr. Genom. 2020, 20, 825-838. [CrossRef]

68. Zhao, X.; Liu, X.; Guo, C.; Gu, J.; Xiao, K. Identification and characterization of microRNAs from wheat (Triticum aestivum L.) under phosphorus deprivation. J. Plant Biochem. Biotechnol. 2013, 22, 113-123. [CrossRef]

69. Ragel, P.; Raddatz, N.; Leidi, E.O.; Quintero, F.J.; Pardo, J.M. Regulation of K+ nutrition in plants. Front. Plant Sci. 2019, 10, 281. [CrossRef] [PubMed]

70. Srivastava, A.K.; Shankar, A.; Chandran, A.K.N.; Sharma, M.; Jung, K.H.; Suprasanna, P.; Pandey, G.K. Emerging concepts of potassium homeostasis in plants. J. Exp. Bot. 2020, 71, 608-619. [CrossRef] [PubMed]

71. Yan, Y.; Wang, H.; Hamera, S.; Chen, X.; Fang, R. MiR444a has multiple functions in the rice nitrate-signaling pathway. Plant J. 2014, 78, 44-55. [CrossRef] [PubMed]

72. Zeng, J.; Ye, Z.; He, X.; Zhang, G. Identification of microRNAs and their targets responding to low-potassium stress in two barley genotypes differing in low-K tolerance. J. Plant Physiol. 2019, 234-235, 44-53. [CrossRef] [PubMed]

73. Ye, Z.; Zeng, J.; Long, L.; Ye, L.; Zhang, G. Identification of microRNAs in response to low potassium stress in the shoots of Tibetan wild barley and cultivated. Curr. Plant Biol. 2021, 25, 100193. [CrossRef]

74. Thornburg, T.E.; Liu, J.; Li, Q.; Xue, H.; Wang, G.; Li, L.; Fontana, J.E.; Davis, K.E.; Liu, W.; Zhang, B.; et al. Potassium Deficiency Significantly Affected Plant Growth and Development as Well as microRNA-Mediated Mechanism in Wheat (Triticum aestivum L.). Front. Plant Sci. 2020, 11, 1219. [CrossRef] [PubMed]

75. Fontana, J.E.; Wang, G.; Sun, R.; Xue, H.; Li, Q.; Liu, J.; Davis, K.E.; Thornburg, T.E.; Zhang, B.; Zhang, Z.; et al. Impact of potassium deficiency on cotton growth, development and potential microRNA-mediated mechanism. Plant Physiol. Biochem. 2020, 153, 72-80. [CrossRef]

76. Li, L.; Li, Q.; Davis, K.E.; Patterson, C.; Oo, S.; Liu, W.; Liu, J.; Wang, G.; Fontana, J.E.; Thornburg, T.E.; et al. Response of Root Growth and Development to Nitrogen and Potassium Deficiency as well as microRNA-Mediated Mechanism in Peanut (Arachis hypogaea L.). Front. Plant Sci. 2021, 12, 695234. [CrossRef]

77. Liu, X.; Tan, C.; Cheng, X.; Zhao, X.; Li, T.; Jiang, J. Correction to: miR168 targets Argonaute1A mediated miRNAs regulation pathways in response to potassium deficiency stress in tomato. BMC Plant Biol. 2021, 21, 84. [CrossRef]

78. Kumar, S.; Kumar, S.; Mohapatra, T. Interaction Between Macro- and Micro-Nutrients in Plants. Front. Plant Sci. 2021, 12, 753. [CrossRef] [PubMed]

79. Pandey, N. Role of plant nutrients in plant growth and physiology. In Plant Nutrients and Abiotic Stress Tolerance; Springer: Singapore, 2018; pp. 51-93, ISBN 9789811090448.

80. Astolfi, S.; Celletti, S.; Vigani, G.; Mimmo, T.; Cesco, S. Interaction Between Sulfur and Iron in Plants. Front. Plant Sci. 2021, 12, 670308. [CrossRef]

81. Wang, L.; Chen, K.; Zhou, M. Structure and function of an Arabidopsis thaliana sulfate transporter. Nat. Commun. 2021, $12,4455$. [CrossRef]

82. Li, L.; Yi, H.; Xue, M.; Yi, M. miR398 and miR395 are involved in response to SO2 stress in Arabidopsis thaliana. Ecotoxicology 2017, 26, 1181-1187. [CrossRef]

83. Liang, G.; Yang, F.; Yu, D. MicroRNA395 mediates regulation of sulfate accumulation and allocation in Arabidopsis thaliana. Plant J. 2010, 62, 1046-1057. [CrossRef]

84. Çelik, Ö.; Akdaş, E.Y. Tissue-specific transcriptional regulation of seven heavy metal stress-responsive miRNAs and their putative targets in nickel indicator castor bean (R. communis L.) plants. Ecotoxicol. Environ. Saf. 2019, 170, 682-690. [CrossRef] [PubMed]

85. Wawrzyńska, A.; Sirko, A. To control and to be controlled: Understanding the Arabidopsis SLIM1 function in sulfur deficiency through comprehensive investigation of the EIL protein family. Front. Plant Sci. 2014, 5, 575. [PubMed]

86. Koprivova, A.; Kopriva, S. Molecular mechanisms of regulation of sulfate assimilation: First steps on a long road. Front. Plant Sci. 2014, 5, 589. [CrossRef] [PubMed] 
87. Chiou, T.J. The role of microRNAs in sensing nutrient stress. Plant, Cell Environ. 2007, 30, 323-332. [CrossRef]

88. García-Segura, L.; Pérez-Andrade, M.; Miranda-Ríos, J. The emerging role of MicroRNAs in the regulation of gene expression by nutrients. J. Nutrigenet. Nutr. 2013, 6, 16-31. [CrossRef] [PubMed]

89. Huang, S.Q.; Xiang, A.L.; Che, L.L.; Chen, S.; Li, H.; Song, J.B.; Yang, Z.M. A set of miRNAs from Brassica napus in response to sulphate deficiency and cadmium stress. Plant Biotechnol. J. 2010, 8, 887-899. [CrossRef]

90. Shahbaz, M.; Pilon, M. Conserved cu-microRNAs in arabidopsis thaliana function in copper economy under deficiency. Plants 2019, 8, 141. [CrossRef] [PubMed]

91. Shabbir, Z.; Sardar, A.; Shabbir, A.; Abbas, G.; Shamshad, S.; Khalid, S.; Natasha; Murtaza, G.; Dumat, C.; Shahid, M. Copper uptake, essentiality, toxicity, detoxification and risk assessment in soil-plant environment. Chemosphere 2020, $259,127436$. [CrossRef] [PubMed]

92. Printz, B.; Lutts, S.; Hausman, J.F.; Sergeant, K. Copper trafficking in plants and its implication on cell wall dynamics. Front. Plant Sci. 2016, 7, 601. [CrossRef]

93. Perea-García, A.; Andrés-Bordería, A.; Huijser, P.; Peñarrubia, L. The copper-microrna pathway is integrated with developmental and environmental stress responses in arabidopsis thaliana. Int. J. Mol. Sci. 2021, 22, 9547. [CrossRef] [PubMed]

94. Sun, Z.; Shu, L.; Zhang, W.; Wang, Z. Cca-miR398 increases copper sulfate stress sensitivity via the regulation of CSD mRNA transcription levels in transgenic Arabidopsis thaliana. PeerJ 2020, 2020, e9105. [CrossRef]

95. Abdel-Ghany, S.E.; Pilon, M. MicroRNA-mediated systemic down-regulation of copper protein expression in response to low copper availability in Arabidopsis. J. Biol. Chem. 2008, 283, 15932-15945. [CrossRef]

96. Jiu, S.; Leng, X.; Haider, M.S.; Dong, T.; Guan, L.; Xie, Z.; Li, X.; Shangguan, L.; Fang, J. Identification of copper (Cu) stressresponsive grapevine microRNAs and their target genes by high-throughput sequencing. R. Soc. Open Sci. 2019, 6, 180735. [CrossRef]

97. Yamasaki, H.; Hayashi, M.; Fukazawa, M.; Kobayashi, Y.; Shikanai, T. SQUAMOSA promoter binding protein-like7 is a central regulator for copper homeostasis in Arabidopsis. Plant Cell 2009, 21, 347-361. [CrossRef]

98. Shireen, F.; Nawaz, M.A.; Chen, C.; Zhang, Q.; Zheng, Z.; Sohail, H.; Sun, J.; Cao, H.; Huang, Y.; Bie, Z. Boron: Functions and approaches to enhance its availability in plants for sustainable agriculture. Int. J. Mol. Sci. 2018, 19, 1856. [CrossRef] [PubMed]

99. Ozhuner, E.; Eldem, V.; Ipek, A.; Okay, S.; Sakcali, S.; Zhang, B.; Boke, H.; Unver, T. Boron Stress Responsive MicroRNAs and Their Targets in Barley. PLoS ONE 2013, 8, e59543. [CrossRef] [PubMed]

100. Jyothi, M.N.; Usha, S.; Suchithra, B.; Ulfath, T.K.S.; Devaraj, V.R.; Babu, R.N. Boron toxicity induces altered expression of miRNAs in French bean (Phaseolus vulgaris L.). J. Appl. Biol. Biotechnol. 2018, 6, 1-10. [CrossRef]

101. Lu, Y.B.; Yang, L.T.; Qi, Y.P.; Li, Y.; Li, Z.; Chen, Y.B.; Huang, Z.R.; Chen, L.S. Identification of boron-deficiency-responsive microRNAs in Citrus sinensis roots by Illumina sequencing. BMC Plant Biol. 2014, 14, 123. [CrossRef] [PubMed]

102. Jin, L.F.; Liu, Y.Z.; Yin, X.X.; Peng, S.A. Transcript analysis of citrus miRNA397 and its target LAC7 reveals a possible role in response to boron toxicity. Acta Physiol. Plant. 2016, 38, 18. [CrossRef]

103. Huang, J.H.; Qi, Y.P.; Wen, S.X.; Guo, P.; Chen, X.M.; Chen, L.S. Illumina microRNA profiles reveal the involvement of miR397a in Citrus adaptation to long-term boron toxicity via modulating secondary cell-wall biosynthesis. Sci. Rep. 2016, 6, 22900. [CrossRef]

104. Lu, Y.B.; Qi, Y.P.; Yang, L.T.; Guo, P.; Li, Y.; Chen, L.S. Boron-deficiency-responsive microRNAs and their targets in Citrus sinensis leaves. BMC Plant Biol. 2015, 15, 271. [CrossRef] [PubMed]

105. Huang, J.H.; Lin, X.J.; Zhang, L.Y.; Wang, X.D.; Fan, G.C.; Chen, L.S. MicroRNA sequencing revealed Citrus adaptation to long-term boron toxicity through modulation of root development by miR319 and miR171. Int. J. Mol. Sci. 2019, $20,1422$. [CrossRef]

106. Kayihan, D.S.; Kayihan, C.; Özden Çiftçi, Y. Moderate level of toxic boron causes differential regulation of micrornas related to jasmonate and ethylene metabolisms in arabidopsis thaliana. Turk. J. Botany 2019, 43, 167-172. [CrossRef]

107. Kayihan, D.S.; Aksoy, E.; Kayihan, C. Identification and expression profiling of toxic boron-responsive micrornas and their targets in sensitive and tolerant wheat cultivars. Turkish J. Agric. For. 2021, 45, 411-433. [CrossRef]

108. Kalaji, H.M.; Dąbrowski, P.; Cetner, M.D.; Samborska, I.A.; Łukasik, I.; Brestic, M.; Zivcak, M.; Tomasz, H.; Mojski, J.; Kociel, H.; et al. A comparison between different chlorophyll content meters under nutrient deficiency conditions. J. Plant Nutr. 2017, 40, 1024-1034. [CrossRef]

109. Farhat, N.; Elkhouni, A.; Zorrig, W.; Smaoui, A.; Abdelly, C.; Rabhi, M. Effects of magnesium deficiency on photosynthesis and carbohydrate partitioning. Acta Physiol. Plant. 2016, 38, 145. [CrossRef]

110. Wolf, J.; Straten, S.; Pitann, B.; Mühling, K.H. Foliar Magnesium supply increases the abundance of RuBisCO of Mg-deficient maize plants. J. Appl. Bot. Food Qual. 2019, 92, 274-280. [CrossRef]

111. Ye, X.; Chen, X.F.; Deng, C.L.; Yang, L.T.; Lai, N.W.; Guo, J.X.; Chen, L.S. Magnesium-deficiency effects on pigments, photosynthesis and photosynthetic electron transport of leaves, and nutrients of leaf blades and veins in citrus sinensis seedlings. Plants 2019, 8, 389. [CrossRef]

112. Ma, C.L.; Qi, Y.P.; Liang, W.W.; Yang, L.T.; Lu, Y.B.; Guo, P.; Ye, X.; Chen, L.S. MicroRNA regulatory mechanisms on Citrus sinensis leaves to magnesium-deficiency. Front. Plant Sci. 2016, 7, 201. [CrossRef] [PubMed]

113. Liang, W.W.; Huang, J.H.; Li, C.P.; Yang, L.T.; Ye, X.; Lin, D.; Chen, L.S. MicroRNA-mediated responses to long-term magnesiumdeficiency in Citrus sinensis roots revealed by Illumina sequencing. BMC Genomics 2017, 18, 657. [CrossRef] [PubMed] 
114. Owusu Adjei, M.; Zhou, X.; Mao, M.; Xue, Y.; Liu, J.; Hu, H.; Luo, J.; Zhang, H.; Yang, W.; Feng, L.; et al. Magnesium Oxide nanoparticle effect on the growth, development, and microRNAs expression of Ananas comosus var. bracteatus. J. Plant Interact. 2021, 16, 247-257. [CrossRef]

115. Alejandro, S.; Höller, S.; Meier, B.; Peiter, E. Manganese in Plants: From Acquisition to Subcellular Allocation. Front. Plant Sci. 2020, 11, 300. [CrossRef]

116. Valdés-López, O.; Yang, S.S.; Aparicio-Fabre, R.; Graham, P.H.; Reyes, J.L.; Vance, C.P.; Hernández, G. MicroRNA expression profile in common bean (Phaseolus vulgaris) under nutrient deficiency stresses and manganese toxicity. New Phytol. 2010, 187, 805-818. [CrossRef]

117. Gong, J.; Li, D.; Li, H.; Zhou, H.; Xu, J. Identification of manganese-responsive micrornas in arabidopsis by small rna sequencing. Czech J. Genet. Plant Breed. 2019, 55, 76-82. [CrossRef]

118. Przybyla-Toscano, J.; Boussardon, C.; Law, S.R.; Rouhier, N.; Keech, O. Gene atlas of iron-containing proteins in Arabidopsis thaliana. Plant J. 2021, 106, 258-274. [CrossRef]

119. He, L.; Yue, Z.; Chen, C.; Li, C.; Li, J.; Sun, Z. Enhancing iron uptake and alleviating iron toxicity in wheat by plant growthpromoting bacteria: Theories and practices. Int. J. Agric. Biol. 2020, 23, 190-196. [CrossRef]

120. Rout, G.R.; Sahoo, S. Role of Iron in Plant Growth and Metabolism. Rev. Agric. Sci. 2015, 3, 1-24. [CrossRef]

121. Jin, L.F.; Yarra, R.; Yin, X.X.; Liu, Y.Z.; Cao, H.X. Identification and function prediction of iron-deficiency-responsive microRNAs in citrus leaves. 3 Biotech 2021, 11, 121. [CrossRef]

122. Kong, W.W.; Yang, Z.M. Identification of iron-deficiency responsive microRNA genes and cis-elements in Arabidopsis. Plant Physiol. Biochem. 2010, 48, 153-159. [CrossRef] [PubMed]

123. Waters, B.M.; McInturf, S.A.; Stein, R.J. Rosette iron deficiency transcript and microRNA profiling reveals links between copper and iron homeostasis in Arabidopsis thaliana. J. Exp. Bot. 2012, 63, 5903-5918. [CrossRef] [PubMed]

124. Carrió-Seguí, À.; Ruiz-Rivero, O.; Villamayor-Belinchón, L.; Puig, S.; Perea-García, A.; Peñarrubia, L. The altered expression of Microrna408 influences the arabidopsis response to iron deficiency. Front. Plant Sci. 2019, 10, 324. [CrossRef]

125. Mousavi, S.R.; Galavi, M.; Rezaei, M. Zink (Zn) Importance for Crop Production. Int. J. Agron. Plant Prod. 2013, 4, 64-68.

126. Sadeghzadeh, B. A review of zinc nutrition and plant breeding. J. Soil Sci. Plant Nutr. 2013, 4, 95162013005000072. [CrossRef]

127. Mattiello, E.M.; Cancellier, E.L.; da Silva, R.C.; Degryse, F.; Baird, R.; Mclaughlin, M.J. Efficiency of soil-applied 67Zn-enriched fertiliser across three consecutive crops. Pedosphere 2021, 31, 531-537. [CrossRef]

128. Shi, D.Q.; Zhang, Y.; Ma, J.H.; Li, Y.L.; Xu, J. Identification of zinc deficiency-responsive MicroRNAs in Brassica juncea Roots by Small RNA Sequencing. J. Integr. Agric. 2013, 12, 2036-2044. [CrossRef]

129. Sinare, B.; Miningou, A.; Nebié, B.; Eleblu, J.; Kwadwo, O.; Traoré, A.; Zagre, B.; Desmae, H. Participatory analysis of groundnut (Arachis hypogaea L.) cropping system and production constraints in Burkina Faso. J. Ethnobiol. Ethnomed. 2021, 17, 2. [CrossRef]

130. Hamza, M.; Abbas, M.; Abd Elrahman, A.; Helal, M.; Shahba, M. Conventional versus nano calcium forms on peanut production under sandy soil conditions. Agriculture 2021, 11, 767. [CrossRef]

131. Song, Q.; Liu, Y.; Pang, J.; Yong, J.W.H.; Chen, Y.; Bai, C.; Gille, C.; Shi, Q.; Wu, D.; Han, X.; et al. Supplementary Calcium Restores Peanut (Arachis hypogaea) Growth and Photosynthetic Capacity Under Low Nocturnal Temperature. Front. Plant Sci. 2020, 10, 1637. [CrossRef]

132. Chen, H.; Yang, Q.; Chen, K.; Zhao, S.; Zhang, C.; Pan, R.; Cai, T.; Deng, Y.; Wang, X.; Chen, Y.; et al. Integrated microRNA and transcriptome profiling reveals a miRNA-mediated regulatory network of embryo abortion under calcium deficiency in peanut (Arachis hypogaea L.). BMC Genom. 2019, 20, 392. [CrossRef] [PubMed]

133. Fan, K.; Fan, D.; Ding, Z.; Su, Y.; Wang, X. Cs-miR156 is involved in the nitrogen form regulation of catechins accumulation in tea plant (Camellia sinensis L.). Plant Physiol. Biochem. 2015, 97, 350-360. [CrossRef] [PubMed]

134. Deboer, K.; Melser, S.; Sperschneider, J.; Kamphuis, L.G.; Garg, G.; Gao, L.L.; Frick, K.; Singh, K.B. Identification and profiling of narrow-leafed lupin (Lupinus angustifolius) micrornas during seed development. BMC Genom. 2019, 20, 135. [CrossRef]

135. Huang, D.; Koh, C.; Feurtado, J.A.; Tsang, E.W.T.; Cutler, A.J. MicroRNAs and their putative targets in Brassica napus seed maturation. BMC Genom. 2013, 14, 140. [CrossRef]

136. De Sousa Cardoso, T.C.; Alves, T.C.; Caneschi, C.M.; dos Reis Gomes Santana, D.; Fernandes-Brum, C.N.; Dos Reis, G.L.; Daude, M.M.; Ribeiro, T.H.C.; Gómez, M.M.D.; Lima, A.A.; et al. New insights into tomato microRNAs. Sci. Rep. 2018, 8, 16069. [CrossRef]

137. Li, C.; Yu, X.; Bai, L.; He, C.; Li, Y. Responses of miRNAs and their target genes to nitrogen- or phosphorus-deficiency in grafted cucumber seedlings. Hortic. Environ. Biotechnol. 2016, 57, 97-112. [CrossRef]

138. Zhang, J.; Lin, Y.; Wu, F.; Zhang, Y.; Cheng, L.; Huang, M.; Tong, Z. Profiling of MicroRNAs and Their Targets in Roots and Shoots Reveals a Potential MiRNA-Mediated Interaction Network in Response to Phosphate Deficiency in the Forestry Tree Betula luminifera. Front. Genet. 2021, 12, 552454. [CrossRef]

139. Paul, S.; Gayen, D.; Datta, S.K.; Datta, K. Analysis of high iron rice lines reveals new miRNAs that target iron transporters in roots. J. Exp. Bot. 2016, 67, 5811-5824. [CrossRef] [PubMed]

140. Hou, G.; Du, C.; Gao, H.; Liu, S.; Sun, W.; Lu, H.; Kang, J.; Xie, Y.; Ma, D.; Wang, C. Identification of microRNAs in developing wheat grain that are potentially involved in regulating grain characteristics and the response to nitrogen levels. BMC Plant Biol. 2020, 20, 1-21. [CrossRef] 
141. Agarwal, S.; Mangrauthia, S.K.; Sarla, N. Expression profiling of iron deficiency responsive microRNAs and gene targets in rice seedlings of Madhukar x Swarna recombinant inbred lines with contrasting levels of iron in seeds. Plant Soil 2015, 396, 137-150. [CrossRef]

142. Chen, M.; Bao, H.; Wu, Q.; Wang, Y. Transcriptome-wide identification of miRNA targets under nitrogen deficiency in populus tomentosa using degradome sequencing. Int. J. Mol. Sci. 2015, 16, 13937-13958. [CrossRef]

143. Zhu, Z.; Li, D.; Cong, L.; Lu, X. Identification of microRNAs involved in crosstalk between nitrogen, phosphorus and potassium under multiple nutrient deficiency in sorghum. Crop J. 2021, 9, 465-475. [CrossRef]

144. Fei, Y.; Luo, C.; Tang, W. Differential expression of microRNAs during root formation in Taxus chinensis var. mairei cultivars Open Life Sci. 2019, 14, 97-109. [CrossRef] [PubMed]

145. Li, X.; Xia, K.; Liang, Z.; Chen, K.; Gao, C.; Zhang, M. MicroRNA393 is involved in nitrogen-promoted rice tillering through regulation of auxin signal transduction in axillary buds. Sci. Rep. 2016, 6, 32158. [CrossRef]

146. Qu, L.; Lin, L.B.; Xue, H.W. Rice miR394 suppresses leaf inclination through targeting an F-box gene, Leaf Inclination 4. J. Integr. Plant Biol. 2019, 61, 406-416. [CrossRef] [PubMed]

147. Zhang, J.; Zhou, Z.; Bai, J.; Tao, X.; Wang, L.; Zhang, H.; Zhu, J.K. Disruption of MIR396e and MIR396f improves rice yield under nitrogen-deficient conditions. Natl. Sci. Rev. 2020, 7, 102-112. [CrossRef]

148. Javed, M.; Sinha, A.; Shukla, L.I. Evaluation of mature miR398 family, expression analysis and the post-transcriptional regulation evidence in gamma-irradiated and nitrogen-stressed Medicago sativa seedlings. Int. J. Radiat. Biol. 2019, 95, 585-596. [CrossRef]

149. Ma, P.; Zhang, X.; Luo, B.; Chen, Z.; He, X.; Zhang, H.; Li, B.; Liu, D.; Wu, L.; Gao, S.; et al. Transcriptomic and genome-wide association study reveal long noncoding RNAs responding to nitrogen deficiency in maize. BMC Plant Biol. 2021, 21, 93. [CrossRef]

150. Yuan, S.; Li, Z.; Li, D.; Yuan, N.; Hu, Q.; Luo, H. Constitutive expression of rice microRNA528 alters plant development and enhances tolerance to salinity stress and nitrogen starvation in creeping bentgrass. Plant Physiol. 2015, 169, 576-593. [CrossRef] [PubMed]

151. Ren, Y.; Sun, F.; Hou, J.; Chen, L.; Zhang, Y.; Kang, X.; Wang, Y. Differential profiling analysis of miRNAs reveals a regulatory role in low N stress response of Populus. Funct. Integr. Genom. 2015, 15, 93-105. [CrossRef] [PubMed] 